\title{
NOTES
}

\section{AIDS AND ERISA PREEMPTION: THE DOUBLE THREAT}

\author{
JAMES R. BRUNER*
}

Dedicated to T.R.H., R.L.M., and people everywhere fighting the virus.

John McGann had been employed by the Dallas-based $\mathrm{H} \& \mathrm{H} \mathrm{Mu}-$ sic Co. ( $H \&$ \& $)$ since 1982. In December of 1987, he informed $H \& H$ that he had Acquired Immunodeficiency Syndrome (AIDS). At that time, $\mathbf{H} \& \mathbf{H}$ provided health insurance for its employees through a group policy it purchased from General American Life Insurance Co. (GAL). That policy placed a $\$ 1$ million lifetime limit on inajor medical benefits. Seven inonths later, in July of $1988, \mathrm{H} \& \mathrm{H}$ changed its fully insured health plan to a self-nisured plan administered by GAL. H \& $\mathbf{H}$ then reduced AIDS benefits to a maximum of $\$ 5000$. The ceiling for other conditions and illnesses remained at $\$ 1$ million. ${ }^{1}$

McGann filed a coinplaint with the Texas Commission on Human Rights alleging discrimination on the basis of handicap. In 1989, he received a right-to-sue notice from the Coinınission. McGann brought suit in the Southern District of Texas alleging discrimination and a violation of rights under the Employee Retirement Incoine Security Act of 1974 (ERISA). ${ }^{2}$ Judge Norman W. Black held that because McGann had not been denied compensation on any of his claims, his claim of discrimination inust fail. ${ }^{3}$ Furthermore, the court noted that ERISA did not require any specific benefits, nor did it prohibit employers from changing

* The author wishes to thank Professor Deborah DeMott of Duke Law School and Professor Arthur Leonard of New York Law School for their assistance and support of this project.

1. Jerry Giesel, Self-Insurers Can Limit AIDS Benefits: Court, CraIN's Bus. Ins., Aug. 6, 1990, at 1; see also Company May Place Cap on AIDS Benefits Without Violating ERISA, Judge Rules, Daily Lab. Rep. (BNA) No. 140, at A-3 (July 20, 1990) [hereinafter Company May Place Cap]. Storehouse, Inc. is another example of a company that reduced its health plan coverage for AIDS to $\$ 25,000$ from a previous limit of $\$ 1$ milhon. See Owens v. Storehouse, Inc., 773 F. Supp. 416, 418 (N.D. Ga. 1991).

2. H \& H Music Co. v. McGann, 742 F. Supp. 392 (S.D. Tex. 1990). ERISA is codified at 29 U.S.C. $\$ \S 1001-1461$ (1988).

3. See $H \& H$ Music, 742 F. Supp. at 394. 
the terms of employee health plans. ${ }^{4}$ Because the defendant had complied with the technical requirements for changing benefit plans, the court granted the defendant's motion for summary judgment. 5 H \& H's switch to a self-insured health plan and subsequent reduction in AIDS coverage exemplifies the problem this Note addresses.

Employers are able to discriminate against people with AIDS (PWAs) by taking advantage of the ERISA preemption doctrime. ${ }^{6}$ Congress designed ERISA to be a new, coinprehensive law governing employer-provided pension and welfare benefit plans. ${ }^{7}$ ERISA was intended to increase employee rights in pension and benefit plans and to ease the regulatory burden on employers by replacimg all state laws relating to pension and benefit plans witl the new federal law. ${ }^{8}$ To eliminate state regulation in the field, Congress included a broadly worded preemption clause that completely preeinpted the field of pension and benefit plans. 9 In ERISA cases, the Supreme Court has emphasized the inportance of preemption, quoting Representative Dent as describing " the reservation to Federal autliority [of] the sole power to regnlate the field of einployee benefit plans' as ERISA's 'crowning aclievement." "10

ERISA preemption has been the source of substantial confusion and litigation, and the courts lave gradually expanded the contours of ERISA's preemptive effect. In FMC Corp. $v$. Holliday, ${ }^{11}$ the Supreme Court's most recent opinion on the subject, the Court expanded ERISA preemption again-this time devising an anomalous distinction between two types of employer-provided lealth plans, ${ }^{12}$ which created a loophole

4. See id. at 393-94.

5. See id. at 394.

6. The doctrine was developed through a series of Supreme Court cases that interpreted ERISA to preempt various state law-based actions. See Pilot Life Ins. Co. v. Dedeaux, 481 U.S. 41 (1987) (interpreting ERISA to prevent state common law actions for alleged improper processing of a benefit claim under an employee benefit plan); Shaw v. Delta Air Limes, Inc., 463 U.S. 85 (1983) (holding that ERISA preempts New York's Human Rights Law insofar as it prohibits practices that are lawful under federal law); see also Eric C. Sohlgren, Group Health Benefits Discrimination Against AIDS Victims: Falling Through the Gaps of Federal Law-ERISA, The Rehabilitation Act and the Americans with Disabilities Act, 24 Loy. L.A. L. REv. 1247, 1251 (1991). Sohlgren may be the first commentator to refer to the Supreme Court's decisions on ERISA preeinption in the 1980s as "the ERISA preemption doctrine." The term is descriptive of the line of Supreme Court decisions that began with Shaw and Pilot Life but was not used by the Court. The term seems appropriate, however, in light of the Court's substantial alterations of this area of law over the past ten years. See also Henry T. Greely, AIDS and the American Health Care Financing System, 51 U. PrTr. L. REV. 73, 106-07 (1989).

7. See Pilot Life, 481 U.S. at 44.

8. Id. at 46 .

9. ERISA § 514(a), 29 U.S.C. $§ 1144($ a); see also FMC Corp. v. Holliday, 111 S. Ct. 403, 407 (1990).

10. Pilot Life, 481 U.S. at 46.

11. 111 S. Ct. 403 (1990).

12. Id. at 409-10; see infra notes $\mathbf{1 3 2 - 3 4}$ and accompanying text. 
that allows employers to avoid all state regulation of their employee health plans. Employers like $\mathrm{H} \& \mathrm{H}$ have used this new freedom from state imsurance law to discriminate against PWAs by severely limitimg or even eliminating coverage for AIDS.

The holding in FMC Corp. was foreshadowed by dicta im an earher ERISA preemption case. In 1985, the Supreme Court suggested in Metropolitan Life Insurance Co. v. Massachusetts ${ }^{13}$ that ERISA may preempt state law and health insurance regulations with respect to selfinsured ERISA welfare benefit plans (health plans). ${ }^{14}$ Since that decision, employers have been able to avoid state insurance regulation by changing from more traditional health plans to self-insured health plans. ${ }^{15}$ The effect of switching to a self-insured plan is to become completely free from state health insurance regulation. Thus, once an einployer has switched to a self-insured plan, it is then free to eliminate or reduce health benefit coverage for AIDS. Being free from all state health insurance regulation, the einployer inay establish or eliminate any plan benefits it chooses; however, there does not appear to be any trend to exclude any particular conditions from coverage other than AIDS. ${ }^{16}$

The freedom of einployers to eliminate coverage for AIDS from the benefits provided by their self-imsured health plans inay drannatically reduce or eliminate AIDS patients' access to health care. The derial of health care to patients with a particular terminal illness is not the only issue raised by this development. The problem raises a legal question about the equity of allowing employers to discriminate at will against employees on the basis of their health status. Should employers be allowed to decide that certain illnesses will be fully covered, but that AIDS (or others) will be completely excluded from the coverage of their health plans? ${ }^{17}$ Related questions about the legal development that created this problem are the primary focus of this Note.

13. 471 U.S. 724 (1985).

14. See id. at $724-25$.

15. This Note focuses on the Supreme Court's legal distinction between self-insured ERISA health plans and employer-sponsored plans that purchase insurance from a commercial insurance company. Plans that purchase insurance are referred to as "traditional" or "purchased" plans. In this Note, these plans will be referred to as "purchased" plans (for ease of reference), but it should be emphasized that these plans are not purchased; rather, the employer has simply purchased group insurance for its employees covered by the employer's group benefit plan. Thus, it is only insurance-not the plan itself--that is purchased.

16. See Sohlgren, supra note 6, at 1258 ("[E]mployers rarely target a particular illness or condition for reduced coverage.").

17. See infra notes 66-69. Historically, the answer in the United States has been no. Regulations in all $\mathbf{5 0}$ states place limits upon discrimination among insureds, and limits on insurance contracts evince a strong policy presnmption against allowing complete freedom of contract in the field of health insurance. 
Until 1990, the distinction between the preemptive effect of ERISA on self-insured and purchased health plans was not firmly established in the law. A difference of opinion developed annong the United States courts of appeals as to the holding and implications of Metropolitan Life. ${ }^{18}$ In 1990, the Supreme Court granted certiorari in FMC Corp. to resolve the conflict and clarify the distinction between self-insured and purchased health plans. ${ }^{19}$

In that case, FMC Corporation brought suit against Cynthia Ann Holliday, the daughter of an employee, seeking a declaratory judgment that FMC was entitled to subrogation for anounts it had paid for her medical care. In 1987 Holliday had been seriously injured in an automobile accident. Her father, Gerald Holliday, brought a negligence action against the driver of the car in which she was injured. The claim was settled out of court. FMC claimed that it was entitled to reimbursement from Holliday's settlement under the subrogation term in its health plan for the money it had paid for Holliday's medical expenses. Holliday's position was that Section 1720 of Pennsylvania's Motor Vehicle Financial Responsibility Law canceled FMC's subrogation right.20

Judge Alan N. Bloch of the U. S. District Court for the Western District of Pennsylvaina granted defendant Holliday's motion for suinmary judgment. That court held that FMC had no subrogation right under Pennsylvamia law and that the Pennsylvania law was not preempted by Section 514 of ERISA. ${ }^{21}$ A unanimous panel of the Court of Appeals for the Third Circuit affirmed.22 In an opinion by Justice

18. Compare Baxter v. Lynn, 886 F.2d 182, 186 (1989) (holding state insurance law on subrogation preempted with respect to a self-insured benefit plan) and Reilly v. Blue Cross \& Blue Shield United of Wis., 846 F.2d 416, 425 (7th Cir. 1988) (holding state law claims for breach of fiduciary duty, conspiracy, fraud, and bad faith in failing to pay for in vitro fertilization preempted with respect to a self-insured benefit plan) with FMC Corp. v. Holliday, 885 F.2d 79, 89-90 (3d Cir. 1989) (holding that ERISA does not preempt anti-subrogation provision of Pennsylvania Motor Vehicle Financial Responsibility Law because such insurance law does not conflict with a core ERISA concern) and Northern Group Servs., Inc. v. Auto Owners Ins. Co., 833 F.2d 85, 95 (6th Cir. 1987) (holding coordination of benefits section of Michigan's No-Fault Automobile Insurance Act not preempted by ERISA because it was not a pretext to restrict ERISA plans and state had interest in Inaintaining primacy in the regulation of insurance).

19. See FMC Corp., 111 S. Ct. at 403.

20. At the time of the suit, Section 1720 provided:

In actions arising out of the nuaintenance or use of a inotor vehicle, there shall be no right of subrogation or reimbursement from a clainant's tort recovery with respect to workers' compensation benefits, benefits available under Seetion 1711 (relating to required benefits), 1712 (relating to availability of benefits) or 1715 (relating to availability of adequate linits) or benefits in beu thereof paid or payable under Section 1719 (relating to coordination of benefits).

75 Pa. Cons. Stat. ANN. $\S 1720$ (Supp. 1991, Historical \& Stat. Notes).

21. FMC Corp. v. Holliday, 731 F. Supp. 710, 713, 716 (W.D. Pa. 1989).

22. See FMC Corp. v. Holliday, 885 F.2d 79, 80 (3d Cir. 1989). The panel consisted of Chief Judge Gibbons, Circuit Judge Hutchinson, and District Judge Wolin sitting by designation. 
O'Connor, the Supreme Court reversed, holding that Section 514 of ERISA preempted the Pennsylvania statute with respect to FMC's selfinsured health plan. ${ }^{23}$

This Note examines the Supreme Court's decision in FMC Corp., which solidified the legal distinction between the effect of ERISA preemption with respect to self-insured health plans and purchased health plans. The Court held that purchased plans are subject to indirect regulation because states may regulate commercial insurance coinpanies and the insurance contracts that they sell. ${ }^{24}$ It also held that self-insured plans are not subject to such regulations because they do not purchase coverage from the regulated commercial carriers, and because the deemer clause ${ }^{25}$ prevents states from regulating health plans directly. ${ }^{26}$

The discussion that follows is divided into two Parts. Part I describes the United States' health care financing system focusing on private insurance and the insurance industry's response to AIDS. On its face, the potential impact of the Court's decision on all beneficiaries of self-insured group health plans is readily apparent. But to appreciate fully the decision's potential impact on PWAs requires a review of both insurance fundamentals and the history of the conflict between the insurance industry and PWAs.

Part II examines the FMC Corp. decision in detail, reviewing alternative judicial interpretations of the relevant subsection of ERISA, offering one additional interpretation, and offering as a final alternative, a judicial application that is arguably consistent with the Court's reasoning but avoids the undesirable results. More specifically, this Note presents four argunients. First, the distinction drawn by the Court in FMC Corp. and its corresponding result are not required by the language of ERISA or by the legislative history. Second, FMC Corp. creates an anomalous result by leaving millions of Americans with no substantive health insurance law protection. Third, even if the FMC Corp. Court's interpretation of ERISA is consistent with portions of the legislative history, Congress never intended the distinction drawn by the Court, nor did it intend to preempt state insurance law froin covering the leading source of private health insurance. Finally, because of employers' efforts to exploit this loophole and avoid state insurance law through self-insuring, and especially because this freedom has been used to discriminate against PWAs, courts and Congress should restore the original effect and protection afforded by state regulation of health insurance. Ideally, Congress should

23. See FMC Corp., $111 \mathrm{~S}$. Ct. at 411.

24. See id. at 409.

25. See infra note 100.

26. See FMC Corp., 111 S. Ct. at 409. 
amend the deemer clause to make clear that self-insured employer-sponsored health plans are governed by state insurance law. But in the absence of congressional action, the Supreme Court should rethink its decision in FMC Corp. There is nore than adequate ambiguity in the existing language and compelling evidence in the legislative history for the courts to effect the same result.

\section{The Private Insurance Industry and Its Response to the AIDS CRISIS}

\section{A. The Trend Toward Smaller Risk Pools for Group Insurance}

Changes in the way private group health plans spread risk have increased cost pressure on such plans to avoid people with above-average health risks such as PWAs. Switching from purchased plans to self-insured plans is part of a continuing trend toward sinaller insurance pools. Smaller risk pools provide cost savings for employers and other insurers providing group health insurance. ${ }^{27}$

Historically, the cost of group policies was estabhished through coinmunity rating of risk pools; later, the cost was determined through experience ratings. ${ }^{28}$ Experience rating was the first step in the cost-saving trend. Smaller health insurance pools permit an insurance company to match more closely risks and costs, thereby accruing savings to presumably healthier groups. ${ }^{29}$

27. Generally, private insurers have employed various approaches to insure health risks that have favored either one or the other of two primary features of insurance: cost and risk spreading on the one hand; or underwriting, which can be thought of as cost and risk matching, on the other. Underwriting-the process of predicting risk and matching the corresponding costs through some evaluation of an insurance policy applicant-historically has been applied only to persons seeking individual policies. See Barry P. Wilson, Health Insurance, in AIDS AND THE LAw 195 (William H. L. Dornette ed., 1986); Karen A. Clifford \& Russel P. Iuculano, AIDS and Insurance: The Rationale for AIDS-Related Testing, 100 HARV. L. REv. 1806, 1809 (1987).

28. For a detailed explanation of the changes from commumity-rated health insurance pools to experience-rated pools and finally to self-insured plans, see Robert A. Padgug \& Gerald M. Oppenheimer, AIDS, Health Insurance, and the Crisis of Community, 5 Notre DAME J.L. ETHICS \& PUB. PoL'Y 35, 38 (1990). The community ratimg system of cost calculation was first employed in the 1930 s by Blue Cross \& Blue Shield. Costs and risks were spread across an entire insured population or community that was covered by the same type of group policy, with equal premiums for all members. Because the community rating model employed the largest liealth insurance pools, it maximized the cost and risk spreading feature of insurance. Costs were sufficiently spread so that underwriting was unnecessary. Cost and risk spreading are intuitively attractive only in a world in which predicting each individual's risks is difficult.

29. See id. Experience rating is a system of insurance pricing which establishes each period's premium level based on the group's claims experience for the prior period. Experience rating for employee insurance pools allowed commercial carriers to decrease the cost of premiums, because employee groups were generally liealthier than the population overall. The unemployed were by definition excluded from such pools, as were most of the very young, very old, and poor. Id.; see also Deborah A. Stone, AIDS and the Moral Economy of Insurance, 1 AM. PROSPECT 62, 63.68 (1990). 
In the past decade this trend toward closer cost and risk matching has also been partially justified on the asserted mequity of cross-subsidization. As health risks have become increasingly identifiable and quantifiable, some have argued that risk pooling of insureds with measurably different health risks creates a forced subsidy from the healthy to the less healthy. ${ }^{30}$ Although some suggest that such a "subsidy" is unfair, ${ }^{31}$ the Supreme Court has noted that grouping people with different risks is common:

[W] hen insurance risks are grouped, the better risks always subsidize the poorer risks. Healthy persons subsidize medical benefits for the less healthy; unmarried workers subsidize the pensions of married workers; persons who eat, drink, or smoke to excess may subsidize pension benefits for persons whose habits are more temperate. Treating different classes of risks as though they were the same for purposes of group insurance is a common practice that has never been considered inherently unfair. ${ }^{32}$

The insurance industry and some commentators describe accurate underwriting as a prerequisite to insurance equity. ${ }^{33}$ This is the theoretical basis the industry has adopted to attempt to justify excluding PWAs from group insurance plans. However, if the principle behind underwriting were taken to the extreme, cross-subsidization from the healthier to the less healthy could be entirely eliminated. Under such a system, each individual would pay precisely for her own risk, reducing insurance to personal savings plans administered by insurance companies rather than banks. ${ }^{34}$

The trend toward smaller risk pools proceeded to the next logical step in the late 1960s with the development of self-insured (also called self-funded) health plans. ${ }^{35}$ Under traditional, commercially provided health insurance for employee groups, the risks are shared by the employer and insurer, and are perhaps spread further to the extent that the commercial carrier provides group policies to other employers. Under self-insured plans, by contrast, the employer bears all of the risk, and the risk cannot be spread beyond its own employee pool. For this reason, employers using self-insured plans havc the highest incentive to limit their medical claims exposure by, for example, excluding coverage for AIDS.

30. See Clifford \& Iuculano, supra note 27 , at 1810 .

31. See, e.g., Joyce N. Hoffman \& Elizabeth Z. Kincaid, AIDS: The Challenge to Life and Health Insurers' Freedom of Contract, 35 DRAkE L. REV. 709, 771 (1986-1987).

32. City of Los Angeles Dep't of Water \& Power v. Manhart, 435 U.S. 702, 710 (1978) (emphasis added).

33. See, e.g., Clifford \& Iuculano, supra note 27, at 1809.

34. See Stone, supra note 29 , at 65.

35. Padgug \& Oppenlieimer, supra note 28 , at 38. 
The simple principle behind shrinking risk pools is that the smaller the risk pool, the greater the pressure to exclude individuals who inay have above-average health risks and would therefore impose above-average costs on the group plan. Therefore, structural changes in health coverage toward smaller risk pools and finally to self-insured employee groups has increased the cost pressure on employers to limit claims exposure. One way that a health plan nnanager can limit plan exposure is to exclude or limit coverage for certain illnesses. This option has rarely been used, but exainples such as $H$ \& H's cap on AIDS coverage suggest that it may be a viable cost containment measure if the coverage eliminated is not important to the einployee beneficiaries.

\section{B. Background of the Conflict Between Insurers and PWAs}

Recent efforts to exclude PWAs from group health plans or to limit health plan benefits (impose "benefit caps") for HIV-related conditions should be viewed as "round two" in the ongoing battle between insurers and PWAs. ${ }^{36}$ The health insurance industry has been in conflict with PWAs since the 1mid-1980s. ${ }^{37}$ The central issue during this first round of the conflict was the right of insurance companies to deny coverage to PWAs (and other persons who are HIV-antibody positive) by testing policy applicants for HIV antibodies. ${ }^{38}$ This history of health insurers' attempts to exclude coverage for PWAs demonstrates their motive and willingness to exclude coverage for PWAs whenever possible. Because various state laws limit employers' and insurers' ability to exclude coverage for PWAs, apphicability of these state laws to all group health plans is vital to PWAs' access to medical care. ${ }^{39}$ The Supreme Court's holding in FMC Corp. that ERISA preeinpts such laws with respect to self-insured health plans gives entployers and their plan administrators a back door through which to avoid state law. To the extent that state law protects PWAs' access to inedical care, the FMC Corp. holding gives employers a tool with which to deny that access.

36. The insurance industry has been on one side of the conflict in opposition to several different groups. PWAs, AIDS activists, gay and lesbian rights groups, and others have opposed the efforts of the insurance industry to exclude PWAs. Because the opposition groups are diverse, they will be referred to in the subsequent discussion as the "anti-industry" group to distinguish them from the "pro-industry" commentators.

37. See Stone, supra note 29, at 62; see also Benjamin Schatz, The Aids Insurance Crisis: Underwriting or Overreaching?, 100 HARV. L. REV. 1782, 1784-86 (1987).

38. The battle over testing prinarily applied to applicants for individual health insurance policies, not for coverage under employer-provided group policies. See Hoffman \& Kincaid, supra note 31, at 717 n.51. See generally Clifford \& Iuculano, supra note 27; Nancy Perkins, Prohibiting the Use of the Human Immunodeficiency Virus Antibody Test by Employers and Insurers, 25 HARV. J. ON LEGIS. 275 (1988).

39. See infra notes 67-69 (discussing state law protection). 
The health insurance industry characterized AIDS as a challenge to the existing health care financing system, arguing that without the right to test new policy applicants, insurance companies would not be able to protect low-risk groups from liaving their insurance pools infiltrated by people with the virus. This argument confused the debate because group policies were not at issue in the testing debate. ${ }^{40}$

Pro-industry commentators suggested that laws restricting premium rate changes would force other pohicyliolders and stockholders to shoulder "unfavorable and unanticipated claim experience" if HIV antibody positive people were allowed to buy individual health insurance policies. ${ }^{41}$ They argued that such cross-subsidization from the healthy to the less liealthy was inequitable and counter to traditional underwriting principles. ${ }^{42}$

Pro-industry commentators also intinated that the insurance industry would be saddled with more than its share of the nation's HIV-related health bill. ${ }^{43}$ Other commentators liave deinonstrated facts that

40. Industry advocates attempted to incite public opinion against PWAs by deceptively suggesting that the prolibition of testing would affect the industry generally. See Padgug \& Oppenheimer, supra note 28 , at 35 . The suggestion was false because it implied that the testing controversy applied to group healtlı policies in addition to individual lealtlı policies. The pro-industry commentators cliose to omit that, although underwriting is common for individual liealtl insurance, it has listorically not been the practice for group plans provided tlirough employers. The conflict over testing was, therefore, irrelevant to beneficiaries of most group liealth plans. Thus, suggesting that people witl HIV infection and AIDS posed a tlireat to tlie entire system of private insurance was false. In fact, the individual policies (to which the testing controversy was relevant) comprise only a small portion of the healtlı insurance industry. See Stone, supra note 29, at 69-70.

Opponents of HIV antibody testing won early victories. Gay and lesbian rights groups and otliers concerned about protecting PWAs persuaded state legislatures, first in California, then in Wisconsin, New York, Florida, Wisconsin, Massacliusetts, and the City Council of the District of Columbia, to pass laws prolibiting insurers from testing applicants for HIV antibodies. Id. at 63. The insurance industry mounted an all-out effort to have these regulations repealed. By the end of 1989, only California's ban on testing lealtli insurance applicants remained. Id. A 1988 congressional survey revealed that most insurers exercise this riglit. See Suzanne M. Russell, Note, Prohibiting AIDS Testing in the Health Insurance Context: Patching Up a Patchwork System, 5 NOTRE DAME J.L. ETHICS \& PuB. POL'y 131, 132 (1990).

The restricted use of underwriting only for individual health imsurance policies is clianging, partially as a result of rising cost pressures from the shrinking size of employer-funded insurance pools. More and more employers and insurance companies are requiring HIV antibody tests or responses to questions about antibody status as prerequisites to memberslip in group plans. See Stone supra note 29, at 69; supra note 35 and accompanying text.

41. See Hoffman \& Kincaid, supra note 31 , at 770 .

42. This is the equity/cross-subsidy argument described at supra notes 31-33 and accompanying text.

43. Industry advocates suggested that forcing the insurance industry to cover HIV-positive people would lead to financial insolvency, eventually forcing insurance companies to rely on their reserves to ineet claim payments. They also argued that prolibiting testing would lead to the industry's collapse, at whicl1 point government would be "forced to step in and once again put tle burden of catastroplic healtli care payments back onto the taxpayer." Hoffman \& Kincaid, supra note 31, at 770 . 
suggest otherwise: "Recent studies have estimated that of all people with AIDS, Medicaid covers 40 to 50 percent nationwide, while private insurance pays for only about 17 percent (and that share is probably declining)."44 Thus, while pro-industry commentators argued that prohibiting testing would ruin the private health insurance industry and thus ultiinately duinp the cost of AIDS on government, anti-mdustry commentators argued that the refusal of private insurance industry to cover the cost of AIDS had already forced the burden onto the public sector. ${ }^{45}$ Although some pro-industry commentators have atteinpted to put the cost arguments in more concrete terms, ${ }^{46}$ anti-industry coinmentators have severely criticized the industry for its inanipulation of cost estimates, describing their assertions as "highly alarmist and, indeed, selfserving on the part of soine in the health insurance industry." 47

Although the perception that medical treatment for AIDS and HIVrelated inedical conditions is expensive is part of the motivation for their exclusion from some group health plans, financial considerations alone cannot fully explain why AIDS is singled out for different coverage than

44. Stone, supra note 29, at 69. For other estimates of the cost of medical treatment for PWAs and the portion of such costs borne by the private insurance industry, see Katharine R. Levit et al., National Health Care Spending Trends: 1988, Health AfFaIRs, Summer 1990, at 171, 174; see also Christine Woolsey, AIDS Claims Hit \$1 Billion; Group Health Insurers Pay Bulk, Bus. 1NS., Oct. 29, 1990, at 2.

45. See, e.g. Stone, supra note 29 , at 70 ("As private employers and insurers avoid the sick and high-risk individuals among us, they displace the costs onto the public sector, which simply lacks the resources to meet those demands on top of the others it already faces.").

46. Clifford and Iuculano stated:

The United States Public Health Service estimates that the annual direct cost of health eare for the estimated 171,000 AIDS patients expected to be alive in 1991 will be between eight billion and sixteen billion dollars. This figure assumes a per case cost of $\$ 46,000$ to $\$ 92,000$... . A large portion of these health care costs will be borne by insurance companies. Yet, high as they are, these figures underestimate the total impact of AIDS on the insurance imdustry ....

Supra note 27, at 1806-07 (footnotes omitted).

47. Padgug \& Oppenheimer, supra note 28, at 35 (citing Jesse Green et al., The $\$ 147,000$ Misunderstanding: Overstating the Cost of AIDS (paper presented at the Fifth International Conference on AIDS, Montreal, June 1989) and Daniel M. Fox \& Emily H. Thomas, The Cost of AIDS: Exaggeration, Entitlement, and Economics, in AIDS AND THE HEALTH CARE SySTEM 197 (Lawrence $O$. Gostin ed., 1990)); see also Schatz, supra note 37:

In the first place, insurers liave greatly exaggerated the cost of AIDS. A study commissioned by the CDC estimates the cost of treating people with AIDS to be only $0.2 \%$ of the nation's total personal health care expenditures in 1985 , with a projected rise to $1.4 \%$ by 1991. The same authors estimate the average cost of treating people with AIDS in 1986 to be $\$ 60,000$ to 75,000 per person, far less thian other illnesses. The ACLI and HIAA continue, however, to cite an outdated CDC cost estimate of $\$ 147,000$, even suggesting that it may be 'conservative.' This assertion is particularly outrageous when compared with the industry's own research: a 1986 ACLI/HIAA survey of 372 companies reveals an average liealth insurance claim paid for people with AIDS of $\$ 36,159$ and an average life insurance claim of $\$ 33,471$.

Id. at $1794-95$ (footnotes omitted). 
that provided for other conditions. ${ }^{48}$ Why, in cases like John McGann's, for example, is only AIDS singled out for exclusion? Professor Arthur Leonard of New York Law School, a leading authority on legal issues confronting PWAs, observed: "If [the insurance industry's] problem is money, why did they single out AIDS ... ? Why not say a beneficiary can receive no more than " $X$ " dollars during their lifetime for any illness?" "49 Group health plans that exclude benefits based on a diagnosis of some other life-threatening illness (such as cancer or heart disease) are rare if not non-existent. ${ }^{50}$ The financial predictions standing alone fail to provide persuasive justification for einployers' and the insurance industry's efforts to exclude AIDS patients.

It is likely that the exclusion of coverage for PWAs by employers and imsurance companies is motivated by prejudice against gay men. There is still a perception that AIDS is largely a gay male disease. ${ }^{51} \mathrm{Be}-$ cause gay men are still subjected to widespread societal prejudice (known as "homophobia" or "homohatred"), PWAs are also targets of this prejudice. $^{52}$

Some insurers have discriminated directly against gay men as gay men, perhaps taking homosexuality as a strong correlate with HIV.53

48. AIDS is no more costly to treat than many other life-threatening illnesses. See Sohlgren, supra note 6, at 1259 (explaining that because conditions such as heart attacks and organ transplants can result in "medical expenses far in excess of AIDS" and these conditions have continued to be covered, an employer who has limited coverage for AIDS creates a "strong implication that the AIDS coverage limitation has been motivated by reasons other than reducing expenses") (citing one report comparing lifetime estimated costs for AIDS $(\$ 50,000-\$ 100,000)$, heart attack $(\$ 66,837)$, cancer of the digestive system $(\$ 47,542)$ and paraplegia $(\$ 68,700)$ ); see also Schatz, supra note 37 , at 1794 (The average cost of treating PWAs in 1986 was between $\$ 60,000$ and $\$ 75,000$, "far less than for many other illnesses.").

49. Company May Place Cap, supra note 1, at A-5 (quoting Professor Leonard).

50. See Sohlgren, supra note 6, at 1258.

51. See Dennis Altman, AIDS IN THE Mind of AMERICA 24-26 (1986). For a detailed account of America's madequate response to AIDS, see RANDY SHILTS, AND THE BAND PLAYED ON: Poltitics, People, AND tHe AIDS Epidemic (1987); Susan Sontag, AIDS AND ITS MetaPHORS 24-43 (1989); see also Schatz, supra note 37, at 1786-88.

52. See generally Marshall Kirk \& Hunter MadSen, After The Ball: How America Will Conquer Its Fear and Hatred of Gays in THE '90s (1989). See infra note 56.

53. There are at least three distinct possible motivations for employer discrinination against PWAs. First, an assumption that they are gay. Second, fear and disdain of the disease itself. Third, concern about the potential cost of inedical treatment. It is inportant to understand that these reasons will often be combined and may be interrelated in complex ways. For example, an employer may seek to avoid medical coverage for a PWA because it thinks homosexuality is repugnant or morally wrong, or it may think its self-insured health plans should not have to absorb the costs of treatment for an AIDS patient because most of its einployees are heterosexual and therefore at no risk for AIDS. 
Pro-industry commentators readily admit that some insurance coinpanies use sexual orientation as a criterion for denying policy applications. ${ }^{54}$ These commentators atteinpt to justify using homosexuality as an indicator for AIDS as being "actuarially valid in view of the condition's epidemiology." 55 Procedures used by some insurance coinpanies attenıpting to identify hoinosexuals include looking for "combinations of 'secondary' factors such as geographic location of residence, occupation and niarital status." 56

It seems unlikely, however, that insurers' and employers' discrimination against gay inen is notivated solely by the misperception that honosexuality is an indicator of AIDS. Although some nray think of honrosexuality as a handy surrogate for AIDS, sone apparently find AIDS a convenient rationalization for discriminating against gay nien.

Other reasons for singling-out PWAs (and to a lesser extent all gay inen) for exclusion from medical coverage are obvious and well docuniented. 57 Many Americans see AIDS as fundamentally different from other life-threatening diseases. ${ }^{58}$ Many heterosexual Americans think they are at no significant risk of contracting AIDS. They see AIDS as a self-inflicted condition and attribute blame to the PWA. Viewing it as "soniebody else's problem," they oppose spreading the cost for AIDS as is done for medical care generally. ${ }^{59}$ More importantly, these views of

54. See Hoffman \& Kincaid, supra note 31, at 722 ("[S]exual orientation has of necessity become an important criterion which insurers must consider incorporating into their classification systems.").

55. Id. One study reported that as of 1988,25 percent of adult AIDS patients had been IV drug users and 65 percent of adult AIDS patients were gay or bisexual men without a history of IV drug use. Office of Technology Assessment, United States Congress, Medical Testing AND HEALTH INSURANCE 165 (1988). Although a large percentage of AIDS patients have been gay men, Hoffman and Kincaid's statement assumes that a large percentage of the gay community has AIDS. There is no evidence to support such an assertion.

56. Hoffman \& Kincaid, supra note 31, at 723. Also suspect are single or divorced male applicants who have occupations stereotypically associated with homosexuality or who have named male friends as beneficiaries. Id. "One industry spokesman, for example, was quoted as saying that '[i]f an applicant is a potential homosexual, the underwriters have ways to find out. We can deny coverage. We vouldn't tell them why." " Schatz, supra note 37, at 1787 (emphasis added). One insurance company distributed an "AIDS Profile," which instructed its agents to segregate applications from "single males without dependents that are engaged in occupations that do not require physical exertion." The suspect occupations included "restaurant employees, antique dealers, interior decorators, consultants, florists, and people in the jewelry or fashion business." Id.; see also Ted Gest, AIDS Triggers Painful Legal Battles, U.S. NEWS \& WORLD REP., Mar. 24, 1986, at 73.

57. See New York Commission on Human Rights, Report on Discrimination AGaINST PEOPLE wITH AIDS (1987); Robert J. Blendon \& Karen Donelan, Discrimination Against People with AIDS: The Public's Perspective, 319 NEw ENG. J. MED. 1022, 1023-24 (1988); supra notes 48-49. See generally SHILTs, supra note 51.

58. See SonTAG, supra note 51, at 24-37.

59. See, e.g., Jonathan Tintinger \& Lawrence Simkins, Mandatory AIDS Testing: Factors Infiuencing Public Opinion, 65 PsYCHOL. REP. 835, 842 (1989) (arguing that "[heterosexuals] perceive[] 
AIDS indicate the greatest error of all: that many Americans still beheve that AIDS is a gay disease. 60

AIDS and hoinosexuality are inextricably connected in the minds of most heterosexual Americans. Many heterosexual Americans have a significant fear and disdain of homosexuality. ${ }^{61}$ This contempt for hon1osexuahity has thus adversely affected many Americans' perception of and response to AIDS. Sonie heterosexual Americans want to exclude homosexuals froin "their" health insurance pools and view generally the allocation of limited health care resources in terms of "in-group/out-group" politics. ${ }^{62}$

Although discrimination against gay men is not the subject of this Note, it is an important factor in the exclusion of PWAs and HIV antibody positive people from the private health care financing systein. This discrimination in access to health care implicates the broader question of how we, as a nation, will allocate limited health care resources. The courts will play a major role in answering this question through their interpretations of statutes like ERISA and the Americans with Disabilities Act of $1990 .{ }^{63}$

\section{The Current State of the Conflict: Employers' Evasion of State Insurance Regulation}

The current conflict between insurers and PWAs is regarding group health plans. Unlike the conflict over individual policies, ${ }^{64}$ this round takes several forms and is far more complex. Einployers and insurers have several options to avoid the costs of medical treatnient for PWAs.

AIDS as a generalized but distant social issue"); George Will, Don't Give Insurance to People with AIDS, Kansas CITY TIMES, Aug. 11, 1988, at A-13.

60. Because AIDS is perceived as a "gay" disease, the insurance industry's efforts to avoid covering the costs of inedical treatment for AIDS patients is symptomatic and indicative of America's generally imadequate response to AIDS.

61. See supra note 52 .

62. Casting the challenge of providing health services to PWAs in such stark politieal terms has grave implications far beyond the gay community. The epidemiology of AIDS is changing dramatically. Recent reports suggest newly reported cases of AIDS are increasingly among people of color. See, e.g., AIDS Increasingly Striking Blacks, Hispanics in State, THE BOSTON GLOBE, April 3, 1990, at 1 . The politics of AIDS to date is a warning to those persons inost likely to become inembers of the next high-risk groups for AIDS. Perhaps most significantly for all PWAs are the indications that gay men and IV drug users are being joined by another political "out-group," people of color, such that efforts to secure adequate medical services for PWAs are likely to contimue to be dominated by "in-group/out-group" politics to the further and prolonged detriment of PWAs.

63. 42 U.S.C.A. $\S \S 12101-12213$ (West Supp. 1991).

64. See supra notes $36-38$ and accompanying text. 
One method is to exclude PWAs from joming group plans, which requires some sort of screening prior to employment.65 Another approach is to exclude coverage for AIDS and other HIV-related conditions or to cap benefit levels for such conditions.

Employers with self-insured health plans have replaced the commercial insurance mdustry in this conflict with PWAs. The motivations of the imsurance industry im the battle over testing are now the motivations of employers with self-insured group health plans. The balance of this Note focuses on employers' efforts to cap or exclude medical benefits for AIDS provided by self-insured group health plans. More specifically, this Note will focus on the legal development that facilitates that discriinmation, the Supreme Court's holding in FMC Corp. Before addressing FMC Corp. directly, a few words about state regulation of insurance and the development of self-imsured health plans, and their effect on PWAs, will provide the context in which to understand the significance and potential impact of FMC Corp. on PWAs' access to medical care.

The regulation of insurance is almost exclusively a matter of state law, and all fifty states have regulated discrimination among insureds. ${ }^{66}$ Many states have mandatory minimum benefit laws, and all states have some form of mandated benefits legislation. ${ }^{67}$ Thirteen states and the District of Columbia have laws specifically prohibiting denial of coverage because the insured has AIDS or an AIDS-related condition. ${ }^{68}$ Thus, most states provide some protection to PWAs. ${ }^{69}$

The value and effect of these protections is now in doubt. Because a new legal mechamism affords einployers the choice of ignoring all state insurance regulation with respect to employer-provided health plans, these laws may become largely irrelevant to most of the relationships

65. See Schatz, supra note 37 , at $1784-88$; supra notes $52-56$ and accompanying text. Some employers are directly testing job applicants for HIV antibodies. Some attempt to discriminate against gay men in liring decisions on the assumption that they pose the greatest risk of subjecting a group liealth plan to HIV-related medical costs. Others dischiarge employees upon discovering that they liave AIDS or test HIV positive. Some even discharge employees upon confirmation or suspicion of homosexuality. See also Report of the Presidential Commission on the Human IMMUNODEFICIENCY ViRUS EPIDEMIC 123 (June 24, 1988); INSTITUTE OF MEDiciNe, NATIONAL ACADEMY OF SCIENCES, CONFRONTING AIDS: AN UPDATE 62-64 (1988).

66. Clifford \& Iuculano, supra note 27, at 1809-10; see also Julie Kosterlitz, States Increasing Their Regulation of Health Plans' Benefits, Eligibility Rules, NAT'L J. 2913 (1985).

67. Dale A. Rublee, Self-Funded Health Benefit Plans, 225 JAMA 787, 787 (1986).

68. Schatz, supra note 37, at 1785 n.28 (listing Arizona, California, Delaware, Florida, Kansas, Maryland, Michigan, Minnesota, Missouri, Oregon, Pennsylvania, Soutl Dakota, Tennessee, and the District of Columbia).

69. For examples of sucli laws, see Sollgren, supra note 6, at $1248-49 \mathrm{nn} .6-7$; see also Hilary E. Lewis, Acquired Immunodeficiency Syndrome: State Legislative Activity, 258 JAMA 2410, 2412-13 (1987) (discussing various insurance laws designed specifically to protect PWAs). 
they were intended to govern. ${ }^{70}$ The Supreme Court has declared that Congress preempted all state imsurance laws and regulations with respect to self-insured health plans. ${ }^{71}$ In FMC Corp., the Court held that state laws may reach group health plans only "indirectly" by regulating the insurance contracts or policies sold by commercial insurance companies. ${ }^{72}$ Thus, if an employer purchases insurance from a commercial carrier for its group health plan, its plan nay be regulated "indirectly" because the policy it purchases and the company from which the employer purchases it can still be regulated "directly." The Court declared that if an employer self-insures its health plan, the states niay not regulate it because they may not deem it to be an insurance company or other insurer. ${ }^{73}$ Thus, as self-insured health plans increase in number, there is a corresponding decrease in the domain of state insurance regulation. ${ }^{74}$

The effect of ERISA preemption on private enployer-sponsored group health plans niay have an enormous impact on PWAs' access to health care. Employer-sponsored group health plans are by far the largest source of health benefits, providing access to health care for approxiinately sixty percent of our population. ${ }^{75}$ These group plans account for eighty-one percent of all private health insurance. ${ }^{76}$ Through Medicare, Medicaid, and other programs, governnent affords access to at least some medical services to another twenty percent of the population. ${ }^{77}$ Of the remaining population, about five percent have private individual insurance policies; fifteen percent have no health coverage at all, ${ }^{78}$ their niedical needs falling completely outside the limited, gap-riddled patchwork that is our public health care financing system. With such a large niajority of Americans dependent upon employer-sponsored health plans, ERISA has grown to take on great importance in health nisurance.

Accordingly, discrimination in group health plan benefits may prove niuch more harmful to PWAs than denial of access to individual health insurance. Moreover, because ERISA preemption gives employers a

70. See supra notes $6,11-12$ and accompanying text.

71. See FMC Corp. v. Holliday, 111 S. Ct. 403, 411 (1990).

72. See id. at 408-09.

73. See id. at 410; see also Greely, supra note 6, at 107 (discussing Metropolitan Life Ins. Co. v. Massachusetts, 471 U.S. 724 (1985)).

74. See infra notes 83-86 and accompanying text.

75. Padgug \& Oppenheimer, supra note 28 , at 38 (stating that $60-70 \%$ of large employer groups utilize self-funded plans).

76. Levit, supra note 44 , at 177.

77. Id.

78. $I d$. 
large incentive to self-insure, "it promises to be important for all Americans covered by employment-related health plans."79

Although self-insured plans were first introduced in the late 1960s, their popularity did not dramatically grow until the Supreme Court suggested in Metropolitan Life Insurance Co. v. Massachusetts ${ }^{80}$ that Congress apparently intended ERISA to preempt state insurance law with respect to self-insured health plans. ${ }^{81}$ The ruling "call[ed] attention to the growing tendency of the business community to abandon group health insurance plans for cost savings realized by self-funding employee health benefits."82 Between 1977 and 1987 the market shares of both Blue Cross and Blue Shield and coinmercially insured plans decreased from thirty-eight percent to twenty-four percent and from fifty-three percent to forty percent, respectively. ${ }^{83}$ In dramatic contrast, self-insured plans increased froin nine percent to thirty-six percent of the market. ${ }^{84}$ A Business Insurance survey found that fifty-eight percent of all employers have self-funded health plans, ${ }^{85}$ a surprisingly high percentage considering that inany small employers do not provide any health benefits, and that self-insured plans are often financially impractical for slightly larger employers. More recently, the Health Insurance Association of America found that fifty-six percent of all American employees receive their medical coverage from self-insured health plans, up from fifty-two percent in 1989.86 More Americans now rely on self-imsured health plans for their inedical coverage than any other source; thus, the impact of laws treating these plans is correspondingly significant. ${ }^{87}$

The Supreme Court's interpretation of ERISA's preemption scheme in FMC Corp. will have a direct and substantial effect on beneficiaries of such plans because it has eliminated the effect of all previously applicable

\footnotetext{
79. Greely, supra note 6 , at 106 .

80. 471 U.S. 724 (1985).

81. See id. at 732 .

82. Rublee, supra note 67 , at 787 .

83. Steven DiCarlo \& Jon Gabel, Conventional Health Insurance: A Decade Later, HealTH Care Financing Rev., Spring 1989, at 77, 82.

84. Id.

85. Rublee, supra note 67 , at 787.

86. Cynthia B. Sullivan \& Thomas Rice, The Health Insurance Picture in 1990, HEALTH AFF., Summer 1991, at 104, 110.

87. Although the term "self-insured" is used to distinguish plans that purchase insurance from those that do not, many self-insured plans purchase stop-loss insurance, which caps their exposure at a designated level. In Northern Group Servs., Inc. v. Auto Owners Ins. Co., 833 F.2d 85 (6th Cir. 1987), the Sixth Circuit explained that stop-loss insurance comes into effect only when specified benefit ceilings are exceeded. Under such an arrangement, the plan will pay claims directly from its own resources up to a certain level. After that designated level (which may be freely established by contract) has been reached, the underwriter may then reimburse the employer for excessive claims or pay the extra claims direetly.
} 
state regulatory protection. ${ }^{88}$ The terms of these plans are now completely at the discretion of the employers and plan administrators. Because self-funded plans do not face the same minimum benefit restrictions as other plans, benefits managers are able to use greater discretion in choosing what medical benefits will be provided. ${ }^{89}$

Although ERISA was intended to protect pension and welfare benefit plan beneficiaries, it contains nothing even remotely similar to the state insurance laws now held to have been preempted. All the provisions of ERISA apply to pension plans, but welfare benefit plans only need to meet reporting, fiduciary, and disclosure standards. ${ }^{90}$ ERISA provides no substantive protection with respect to health plans.

One result of this disparate legal treatment is that im the absence of state insurance regulation, the Court's reading of ERISA allows discrimination in several ways. ${ }^{91}$ As the $M c$ Gann case deinonstrates, employers have begun using their new freedom to reduce or eliminate benefits for their employees with AIDS. Professor Arthur Leonard aptly characterized the growing trend of switching to self-insured plans specifically for the purpose of denying coverage to employees with AIDS as " "a ploy that is sweeping the country." "92 These plans can " 'skim' good health risks from bad, im the sense that employers can capture good health risks and encourage poor risks to choose group insurance plans, leading to another sort of adverse selection." 93 Moreover, "[t]he overall social significance of self-funding is the proctivity to reduce or deny access to medical services to some people." 94

This new preemption also creates confidentiality problems. Because "these employers have a direct stake in benefit use, it is possible for employers to use claims records to discriminate against employees with high medical expenses when making appointment, promotion, and retention decisions." 95

The Court's decision in FMC Corp. will almost certainly exacerbate the situation: the growing trend toward self-insured health plans, and the exploitation of these plans' complete freedom from state insurance

88. See supra notes $67-69$ and accompanying text.

89. See Rublee, supra note 67 , at 789.

90. Id. at 787. A pension benefit plan provides income deferral or retirement income. ERISA $\S 3(2), 29$ U.S.C. $\S 1002(2)(A)$ (1988). A welfare benefit plan is any program or plan that provides benefits for contingencies such as illness, accidents, disability, death, or unemployment. Id. § 3(1), 29 U.S.C. § 1002(1); see also Shaw v. Delta Air Lines, Inc., 463 U.S. 85 , 91 n.5 (1983).

91. See supra notes 53-56 and accompanying text.

92. Company May Place Cap, supra note 1, at A-4 (quoting Professor Leonard).

93. Rublee, supra note 67 , at 789.

94. Id. at 788 .

95. Id. at 789 . 
regulation through further exclusions of conditions employers and plan administrators consider either too expensive or too unimportant to cover.

\section{THE ERISA CONNECTION}

\section{A. The ERISA Statute}

ERISA was intended to be a comprehensive and uniform approach to employee pension and welfare benefit plans. ${ }^{96}$ To achieve this goal, Congress had to preempt all state laws that regulated pension and benefit plans. ${ }^{97}$ However, after preempting the field, Congress added a savings clause to exempt state insurance, banking, and securities laws from preeinption. Congress also prevented states froin deeming pension and benefit plans from being deemed insurance companies, banks, trust companies, or investment compamies for certain purposes. Thus, Congress sought to balance the need for a comprehensive pension and welfare benefit plan law and the need to retain certain traditional areas of state law.

Three sections of ERISA are relevant to preemption: the preemption clause; 98 the savings clause; 99 and the deener clause. ${ }^{100}$ The one exception to the preemption clause is the savings clause. The Supreme

\footnotetext{
96. See Pilot Life Ins. Co. v. Dedeaux, 481 U.S. 41 (1987):

Congress set out to "protect ... participants in employee benefit plans and their beneficiaries, by requiring the disclosure and reporting to participants and beneficiaries of financial and other information with respect thereto, by establishing standards of conduct, responsibility, and obligation for fiduciaries of employee benefit plans, and by providing for appropriate remedies, sanctions, and ready access to the Federal courts."
}

Id. at 44 (quoting ERISA § 2,29 U.S.C. $\S 1001(b)$ ).

47.

97. See FMC Corp. v. Holliday, 111 S. Ct. 403, 407 (1990); see also Pilot Life, 481 U.S. at 45 -

98. Section 514(a) provides:

Except as provided in subsection (b) of this section, the provisions of this subehapter and subchapter III of this chapter shall supersede any and all State laws insofar as they inay now or hereafter relate to any employee benefit plan described in seetion 1003(a) of this title and not exempt under section 1003(b) of this title. This section shall take effect on January 1, 1975.

ERISA § 514(a), 29 U.S.C. § 1144(a).

Section 4(a), entitled Coverage, provides:

Except as provided in subsection (b) of this section and in sections 1051, 1081, and 1101 of tlis title, this subchapter shall apply to any employee benefit plan if it is established or maintained-(1) by any einployer engaged in commerce or in any industry or activity affecting commerce; or (2) by any employee organization or organizations representing employees engaged in commerce or in any industry or activity affecting commerce; or (3) by both.

Id. $\S 4(\mathrm{a}), 29$ U.S.C. $\S 1003(\mathrm{a})$.

Subsection 4(b) exempts government, church, workmen's compensation, foreign and "cxcess benefit" plans. See id. § 4(b), 29 U.S.C. § 1003(b). Hence, ERISA applies to all domestic einployerprovided health plans provided by for-profit enterprises.

99. See ERISA \& 514(b)(2)(A), 29 U.S.C. \&1144(b)(2)(A) ("Except as provided in subparagraph (B), nothing in this subchapter shall be construed to exempt or relieve any person from any law of any State which regulates insurance, banking, or securities."). 
Court has construed the savings clause as returning to the states "the power to enforce those state laws that 'regulat[e] iusurance,' except as provided in the deemer clause." 101 There is no debate over the general purpose of the savings clause. There are, however, different interpretations as to what it means when read in light of the deemer clause that follows it. 102

The one exception to the savings clause is defined in the deemer clause. All courts that have spoken on the issue agree that the deemer clause modifies the savings clause in some way. Exactly what its effect is or should be is the subject of the remaining discussion.

\section{B. Legal Background}

Prior to the FMC Corp. decision, the Supreme Court and lower federal courts had noted the ambiguity and complexity of ERISA's preemption scheine. ${ }^{103}$ In three prior cases, the Supreine Court had explamed various aspects of ERISA's preemption scheme. ${ }^{104}$

The Court's opinion in Metropolitan Life Insurance Co. v. Massachusetts directly influenced its opinion in FMC Corp. In Metropolitan Life, the Massachusetts Attorney General brought suit against Metropolitan Life Insurance Company to enforce a section of the state's mandatory benefit statute. The section in question required that any general health insurance policy or health plan that provides hospital and surgical benefits must also provide certain minimum mental health care benefits. ${ }^{105}$ The Attorney General argued that the section was exempted from preemption under the savings clause because it was an insurance law. Metropohtan Life cliaracterized the section as a "health law" and argued that it was outside the scope of the savings clause. ${ }^{106}$

The Supreme Court rejected Metropohtan Life's argument, stating that "it is both historically and conceptually inaccurate to assert that

100. Section 514(b)(2(B) provides:

Neither an employee benefit plan described in section 1003(a) of this title, which is not exempt under section 1003(b) of this title (other than a plan estabhished primarily for the purpose of providimg death benefits), nor any trust established under such a plan, shall be deemed to be an imsurance company or other insurer, bank, trust company, or investment company or to be engaged in the busimess of insurance or banking for purposes of any law of any State purporting to regulate insurance companies, insurance contracts, banks, trust companies, or imvestment companies.

ERISA § 514(b)(2)(B), 29 U.S.C. § 1144(b)(2)(B).

101. FMC Corp., $111 \mathrm{~S}$. Ct. at 407.

102. See, e.g., Metropolitan Life Ins, Co. v. Massachusetts, 471 U.S. 724, 740-41 (1985).

103. See Shaw v. Delta Air Lines, Inc., 463 U.S. 85, 95 (1983) (noting that lower courts have disagreed about the scope of ERISA's preemption provisions).

104. See Pilot Life Ins. Co. v. Dedeaux, 481 U.S. 41 (1985); Metropolitan Life, 471 U.S. at 724; Shaw, 463 U.S. at 85.

105. Metropolitan Life, 471 U.S. at 730.

106. See id. at 741. 
mandated-benefit laws are not traditional insurance laws."107 The Court then cited the McCarran-Ferguson Act ${ }^{108}$ and cases decided thereunder as providing the proper definition of insurance. In a footnote, the Court observed: "The ERISA saving clause, with its similarly worded protection of 'any law of any State which regulated insurance,' appears to have been desigued to preserve the McCarran-Ferguson Act's reservation of the busmess of imsurance to the States." 109 The Court next applied a three-part test, developed by cases interpreting the phrase "business of insurance"110 (used in the McCarran-Ferguson Act), to Massachusetts' mandatory benefit law, and held that it was saved from ERISA preemption. ${ }^{111}$

After holding that the Massachusetts law was saved because it "regulates insurance," the Court observed:

We are aware that our decision results in a distinction between insured and uninsured health plans, leaving the former open to indirect regulation while the latter are not. By so doing we inerely give life to a distinction created by Congress in the "deemer clause," a distinction Congress is aware of and one it has chosen not to alter. ${ }^{112}$

Subsequently, several courts read Metropolitan Life for the proposition that purchased health plans are subject to indirect regulation (i.e., through regulation of companies from whom they purchase insurance by operation of the savings clause), but self-insured plans may not be regulated at all because they cannot be deeined insurance companies or other insurers. ${ }^{113}$

Despite two other Supreme Court opinions on ERISA preemption and the dicta in Metropolitan Life noted above, the question whether there is a legal distinction between self-insured and purchased welfare benefit plans (health plans) divided the Seventh and Eighth Circuits from the Third and Sixth Circuits. ${ }^{114}$ The Seventh and Eighth Circuits held

107. Id. at 742 .

108. 15 U.S.C. $\$ \S 1011-1015$ (1988).

109. Metropolitan Life, 471 U.S. at 744 n.21. Section 1012(a) of the McCarran-Ferguson Act states that "[ $t]$ he business of insurance, and every person engaged therein, shall be subject to the laws of the several states which relate to the regulation or taxation of such business." 15 U.S.C. $\$ 1012$ (a) (1988).

110. That test for the "business of insurance" is "first, whether the practice has the effect of transferring or spreading a policyholder's risk; second, whether the practice is an integral part of the policy relationship between the insurer and the insured; and third, whether the practice is limited to entities within the insurance industry." Metropolitan Life, 471 U.S. at 743.

111. Id. at 744 .

112. Id. at 746-47.

113. See Baxter v. Lynn, 886 F.2d 182, 186 (8th Cir. 1989); Reilly v. Blue Cross \& Blue Shield United of Wis., 846 F.2d 416, 425 (7th Cir. 1988); United Food \& Commercial Workers v. Pacyga, 801 F.2d 1157, 1161 (9th Cir. 1986); Moore v. Provident Life \& Accident Ins. Co., 786 F.2d 922, 927 (9th Cir. 1986).

114. See supra note 18. 
that ERISA preemption does affect self-insured and purchased plans differently. In 1987, in Reilly v. Blue Cross \& Blue Shield, 115 the Seventh Circuit held that state law claims for breach of fiduciary duty, conspiracy, fraud, and bad faith in failing to pay for in vitro fertilization could not be sustained against an employer with a self-insured health plan because ERISA preeinpted all state law claims agamst self-insured health plans. ${ }^{116}$ The next year, in Baxter v. Lynn, ${ }^{117}$ the Eighth Circuit held that, with respect to a self-insured health plan, state insurance law on subrogation was preempted by ERISA. 118

In contrast, in Northern Group Services, Inc. v. Auto Owners Insurance Co. ${ }^{119}$ the Sixth Circuit held that Michigan's No-Fault Automobile Insurance Act was not preempted by ERISA because it was not a pretext for regulatimg ERISA plans. ${ }^{20}$ The Court held that Michigan's law applied to self-insured and purchased health plans alike. In a similar case, FMC Corp. v. Holliday, ${ }^{121}$ the Third Circuit also rejected the distinction between self-insured and purchased plans, holding that ERISA did not preempt Peimsylvania's anti-subrogation law with respect to self-insured health plans. ${ }^{122}$ The court expressly adopted the Sixth Circuit's view and rejected the Seventh and Eighth Circuits' approach. In deciding between the two views, the court emphasized that the deemer clause phrase "purporting to regulate" is the critical source of the difference of opinion. ${ }^{123}$

Both the Third and Sixth Circuits interpreted "purporting to regulate insurance" to refer to laws or regulations that states intended to withstand the general preemption clause by creating the pretext that they were insurance regulations. These two circuits decided that, in the deemer clause, Congress distimguished between bona fide state insurance regulations, which are saved from ERISA preemption, and deceptive attempts by states to expand their regulatory authority by passing off other kinds of laws as imsurance laws. ${ }^{124}$ The Third Circuit stated that "the use of 'purporting' betokens a congressional concern only for regulation that was merely a pretext for impinging upon ERISA plans."12s Thus, "the deemer clause is ineant maiuly to reach back-door attempts by

115. 846 F.2d 416 (7th Cir. 1988).

116. See id. at 425-26.

117. 886 F.2d 182 (8th Cir. 1989).

118. See id. at 186. Both of these decisions explicitly relied on the Metropolitan Life dicta discussed above.

119. 833 F.2d 85 (6th Cir. 1987).

120. See id. at 93-95.

121. 885 F.2d 79 (3d Cir. 1989).

122. See id. at 86-87.

123. See id. at 86 .

124. See id. at 86-87; Northern Group, 833 F.2d at 93.

125. FMC Corp., 885 F.2d at $86-87$ (emphasis added). 
states to regulate core ERISA concerns in the guise of insurance regulation."126 The Sixth Circuit, citing to ERISA's legislative history, concluded that "the final broad version of section 514 that einerged from the conference committee was to avoid intentional-and perhaps pretextual-atteinpts by states to restrict the discretion of ERISA plans to engage im practices that otherwise would be permitted by federal law."127

Thus, the Third and the Sixth Circuits held that it is only for the purpose of state laws that attempt to extend their regulatory authority through specifically pretextual state laws aimed at core ERISA concerns that ERISA plans may not be deemed to be insurance. For example, ERISA imposes various reporting requirements upon welfare benefit plan administrators. Therefore, if a state insurance commission attempted to mipose different reporting requirements through an assertion of its imsurance regulatory authority, such a regulation could be called "pretextual" in that it aimed at a "core" ERISA concern and would thus be outside the scope of the insurance authority reserved to the states through the savings clause.

The Third Circuit further explained that "[a]ny reading other than one confined to the central aspects of ERISA would either have the deemer clause swallow the savings clause or read into the statute other distinctions that are not there." 128 The Third Circuit's view is that because state authority is reserved with respect to insurance, banking, and securities, the deemer clause restricts deeming only when it would affect "core ERISA concerns."129 If it prohibited all deeming, state regulatory authority with respect to insurance, banking, and securities would be greatly diminished (eliminated with respect to benefit plans), and the savmgs clause would thus be "swallowed."

126. Id. at 86. Note that the object of these pretextual state laws, "core ERISA concerns," is separate from the idea of pretextual state laws. The Third Circuit placed substantial emphasis on "core ERISA concerns" that were not essential to the idea of pretextual state regulations.

127. Northern Group, 833 F.2d at 93.

128. FMC Corp., 885 F.2d at 88 (emphasis added). This is a further illustration of the Third Circuit's emphasis on "core ERISA concerns." Other distimctions would be those drawn between regulations allowed and disallowed under the deemer clause. The most problematic example of such distinctions is a bright lime between plans that purchase insurance and those that do not. Other arbitrary distinctions could be drawn on any basis imaginable to distinguish those insurance or banking laws that would be allowed to apply to welfare benefit plans from those not so allowed. Such "disallowed" laws would not be able to deem plans to be the subject the law purported to regulate. The laws allowed would be allowed to so deem welfare benefit plans.

129. See id. The "core ERISA concerns" approach reflects the balance Congress sought between, on the one hand, creating one comprehensive, uniform pension and benefit law, and preserving the traditional regulatory role of the states in areas such as insurance and banking on the other. Therefore, "core ERISA concerns" would be things like benefit managers' fiduciary duties to plan beneficiaries, vesting of benefits, and various reporting requirements-in short, all of the essential, substantive requirements of ERISA. 
In 1990, the Supreme Court granted certiorari in FMC Corp. v. Holliday to resolve this conflict. ${ }^{130}$ Although FMC Corp. settled the judicial conflict, it is unhikely that the Court's opinion will prove persuasive enough to settle the legal debate on the true contours of ERISA preemption and, more specifically, the preemption of state imsurance law with respect to self-insured health plans. This debate derives largely from competing interpretations of the deemer clause.

What follows is an explanation of the FMC Corp. majority interpretation and Justice Stevens dissenting imterpretation of the deemer clause. After an explanation and critique of these competing views, this Note offers an alternative interpretation.

\section{FMC Corp.: Holding and Origins}

1. The Majority's View of the Deemer Clause. ${ }^{131}$ The question presented in FMC Corp. was whether FMC Corporation was entitled to subrogation from Holliday's out of court settlement for medical costs that it had paid. Holliday argued that Pennsylvania's anti-subrogation law prevented reimbursement to the company. FMC Corporation argued that the state law was preempted by ERISA because its health plan was self-insured. ${ }^{132}$

In FMC Corp., after explaining that Pennsylvania's Motor Vehicle Financial Responsibility Law related to FMC's ERISA plan and was saved because it regulated insurance, the Court held that "[s]tate laws that directly regulate imsurance are 'saved' but do not reach self-funded employee benefit plans because the plans may not be deenied to be insurance compames, other insurers, or to be engaged in the business of insurance for purposes of such state law."133 The Court's view was that ERISA plans may be bound by state imsurance law only "insofar as they apply to the plan's insurer," thus, the distinction between self-insured and purchased plans. ${ }^{134}$ Under the Court's conceptualization, states may regulate insurance, but no ERISA plans can be deemed to be insurance companies or other insurers. Therefore, if an employee benefits plan purchases insurance from a regulated insurance company, the plan is regulated to the extent the commercial carrier selling to the plan is regulated. If, however, an employer self-imsures its benefits plan, rather than purchasing insurance, it is free from state regulation because the plan

130. 493 U.S. 1068 (1990).

131. For a statement of the facts and holding in this case, see infra note 134 and accompanying text.

132. FMC Corp. v. Holliday, 111 S. Ct. 403, 406 (1990).

133. Id. at 409.

134. Id. 
cannot be deemed to be an insurer. The Court drew support for its holding from Metropolitan Life, but, as will be explained below, ${ }^{135}$ the Court's reliance on the Metropolitan Life dicta is misplaced.

The Court's holding ignored the qualifier in the deenner clause, "for purposes of any law of any State purporting to regulate insurance."136 The Court rejected the argument that the phrase designates pretextual state legislation, noting that, "Congress' use of the word does not indicate that it directed the deemer clause solely at deceit that it feared state legislatures would practice." 137 After rejecting this interpretation of the phrase, the Court offered no affirmative interpretation of its own.

The effect of the Court's approach-to ignore the deeiner clause's qualification upon the federal proscription of states deeming welfare benefit plans to be insurance companies or other insurers-is to nullify the qualification. The Court decided that states may not deem health plans to be insurers for any purpose, i.e. that states cannot deem welfare benefit plans to be insurers at all. Thus, in effect, the Court's interpretation of the qualifier in the deemer clause inust be that all laws that purport to regulate insurance do, in fact, regulate insurance. ${ }^{138}$ The conceptual problem with this approach to the deemer clause is that the language in the statute is rendered meaningless.

2. Sources Underlying the Majority's Interpretation and Conceptualization of the Deemer Clause. The FMC Corp. inajority derived their approach to ERISA's preemption clauses from two sources: the Metropolitan Life decision; and ERISA's legislative history. The FMC Corp. majority's conceptual problems derive from adopting the framework suggested in Metropolitan Life, ${ }^{139}$ ignoring the fact that Metropolitan Life presented no question under the deemer clause. ${ }^{140}$ The statements from

\footnotetext{
135. See infra text accompanying notes $139-50$.

136. ERISA $\S 514(b)(2)(B), 29$ U.S.C. $\S 1144(b)(2)(B)(1988)$.

137. FMC Corp., 111 S. Ct. at 410.

138. This interpretation of the qualifier is attributed to the majority opinion by inference; the Court did not affirmatively interpret this phrase. Because the Court decided that states may never regulate welfare benefit plans directly, it has decided that there is no qualification upon the federal proscription of states' deeming. Thus, the qualifier has been interpreted right out of the statute. It follows then that the majority's view of laws purporting to regulate insurance is that they do regulate insurance.
}

139. See supra text accompanying note 112.

140. See FMC Corp. v. Holliday, 885 F.2d 79, 89 (3d Cir. 1989); Northern Group Servs., Inc. v. Auto Owners Ins. Co., 833 F.2d 85, 91 (6th Cir. 1987). Metropolitan Life posed no question under the deemer clause because none of the parties were employer-provided welfare benefit plans. Both of the appellants were commercial insurance companies, Metropolitan Life Insurance Co. and Travelers Insurance Company. The law was held applicable to them solely through operation of the savings clause. 
Metropolitan Life that the FMC Corp. majority relied upon are dicta addressing an issue that was not before the Metropolitan Life Court. The question before the Court in Metropolitan Life was whether Massachusetts law requiring certain insurance policies and health plans to provide certain minimum mental health care benefits fell within the scope of the savings clause. ${ }^{141}$ Because the Massachusetts Attorney General brought suit to enforce the state law with respect to "general insurance policies," deeming was not an issue. ${ }^{142}$

The authority for the Metropolitan Life dicta is also questionable. The Court rehed on a House Activity Report as authority for the distimction between self-insured and purchased plans. ${ }^{143}$ In this report, the House Committee on Education and Labor addressed the confusion caused by private parties who market imsurance products claiming that the products are ERISA plans. The report explains that such products "are no more ERISA plans than is any other insurance policy sold to an enployee benefit plan." 144 The Court heavily relied on the following staternent: "To the extent that such programs fail to meet the definition of an 'einployee benefit plan,' state regulation of them is not preempted by section 514, even though such state action is barred with respect to the plans which purchase these 'products.' "145 The statement in the report explams that health insurance policies (the "products" sold to health plans) can be regulated. This statement is a simple explanation of the savings clause. As an afterthought, the statement suggests that health plans that purchase insurance cannot be directly regulated. This statement says nothing about self-msured health plans and draws no distinction between self-insured and purchased plans.

The report further explains: "[W]e do not believe that the statute and legislative history will support the mclusion of what amounts to cominercial products within the umbrella of the definition."146 The point of this statement is to explain that cominercial insurance poticies are not ERISA plans and that these policies can be regulated by states because of the savings clause. Additionally, the report indicates that plans that purchase these commercial policies cannot be regulated.

141. See Metropolitan Life, 471 U.S. at 727.

142. See id. at 724. Moreover, it will be argued that had the question of direct application of the Massachusetts law to a self-insured health plan been raised, Metropolitan Life's dicta would have been an erroneous interpretation of the decmer clause. See infra Part II(E).

143. See Metropolitan Life, 471 U.S. at 747 (citing HouSE COMM. ON EdUCATION AND LABOR, ACTIVITY REPORT, H.R. REP. No. 1785, 94th Cong., 2d Sess. (1977) [hereinafter ActivitY REPORT]).

144. ACTIVITY REPORT, supra note 143, at 48.

145. Id. (einphasis added) (citation oinitted).

146. Id. 
From this report, the Metropolitan Life Court made two assumptions without written analysis. First, that no ERISA plans can be directly regulated by state laws, ${ }^{147}$ and second, that because self-imsured plans do not purchase insurance, they apparently cannot be regulated by state law at all. 148 Although the sentence in the report addressing "state action" provides inferential support for the Court's first assuinption, it provides none for the second. ${ }^{149}$ Coming three years after passage of ERISA, "[t]his post hoc explanation ... is entitled to little weight when it conflicts with a reasonable interpretation of a statute based on its text and its legislative history prior to enactment." 150 The report simply does not speak to the issues of regulation of self-insured plans or to the meaning of the deemer clause.

More important than this explanation and the context of the report is the simple fact that Metropolitan Life did not decide whether ERISA preemption affects self-insured and purchased plans differently because this issue was not before the Court. Therefore, the FMC Corp. Court's attempt to draw support from Metropolitan Life is misplaced. Rather than earefully analyzing the language of the deemer clause, the FMC Corp. majority was satisfied to rely upon Metropolitan Life's casual dicta. ${ }^{151}$

The FMC Corp. majority places additional reliance for its interpretation of the deemer clause on one statement in the House Conference Report accompanying ERISA: ${ }^{152}$

The preemption provisions of title I are not to exempt any person from any State law that regulates insurance, banking or securities. However, the substitute generally provides that an employee benefit plan is not to be considered as an imsurance company, bank, trust company, or investment company (and is not to be considered as engaged in the busimess of insurance or banking) for purposes of any State law that

147. See Metropolitan Life, 471 U.S. at 747.

148. See id.

149. The context of the Report's statement may help explain it. The statement discusses regulation of commercial insurance policies under the savings clause. It adds that health plans that purchase insurance cannot be regulated directly. Because the last phrase appears, in effect, as an afterthought-a way of explaining that plans that purchase insurance are to be regulated indirectly in contrast to direct regulation - it should not be over-emphasized. It was not intended as an explanation of the deemer clause. If taken as such an explanation, it would be glaringly incomplete for its lack of explanation of the phrase "for purposes of state laws purporting to regulate." Indeed, if the deemer clause is read as a blanket prohibition on direet regulation of welfare benefit plans, then this final phrase is reduced to meaningless verbiage. See supra note 136 and aceompanying text.

150. Northern Group Servs., Inc. v. Auto Owners Ins. Co., 833 F.2d 85, 92 (6th Cir. 1987) (citing Consumer Product Safety Comm'n v. GTE Sylvania, 447 U.S. 102, $117-18$ \& n.13 (1980)).

151. See FMC Corp., $111 \mathrm{~S}$. Ct. at 409-10.

152. See id. at 410 (citing H.R. Conf. REP. No. 1280, 93d Cong., 2d Sess. (1974), reprinted in 1974 U.S.C.C.A.N. 5038). 
regulates insurance companies, insurance contracts, banks, trust companies, or investinent companies. ${ }^{153}$

Although this explanation supports the notion that health plans are not to be regulated directly, it need not be the end of the inquiry. There are significant errors in the documents that comprise the legislative history. ${ }^{154}$ There were also several different versions of the bill and soine disagreeinent about inclusion of the deemer clause. ${ }^{155}$ Initially neither the House nor Senate versions of the bill contained a deemer clause. The first deemer clause was not added "until the House substituted the text of H.R. 12906 for that of H.R. 2 just prior to passage of the pre-conference House bill." 156

The conference committee staff was divided on whether the House version with the deeiner clause should be adopted. ${ }^{157}$ At this point in its development, the deeiner clause did not contain the qualifier "for purposes of any law of any State purporting to regulate insurance." Instead, it prohibited deeming "for purposes of any law of any State regulating insurance." 158 Hence the distinction between pretextual laws and other laws did not exist in this initial version of the clause.

As a compromise, staff members suggested that the deemer clause be incorporated, but only for a limited time, such as three years, and

153. H.R. CoNF. REP. No. 1280, supra note 152, at 383, 1974 U.S.C.C.A.N. at 5162.

154. The Sixth Circuit explained:

Compounding the difficulty is a tendency in the legislative history of ERISA to conflate and confuse the three clauses. For exainple, an oversight report issued three years after the enactment of ERISA ... says:

... In general these exemptions are designed to save State laws as it applies to entities which are not employee benefit plans...., to the extent that such regulation does not relate to employee benefit plans.

$\ldots$

These subsequent legislators (or their staff) did not seem to recognize or consider the fact that the "savings" clause would not be necessary at all if it only saves state laws that do not "relate to" ERISA plans. The savings clause would not be necessary to save something that the preemption clause had not reached in the first instance.

Northern Group, 833 F.2d at 89 (citation omitted).

155. See infra note 158.

156. Northern Group, 833 F.2d at 92 (citing H.R. 12906, 93d Cong., 2d Sess. § 514(b) (1974), reprinted in 2 Subcomm. ON LABor of THE Senate Comm. on LABor and Public Welfare, 3 LEGISLATIVE HISTORY OF THE EMPLOYEE RETIREMENT INCOME SECURITY ACT OF 1974, at 2761, 2921 (1976) [hereinafter LEGISLATIVE HISTORY OF ERISA]).

157. Id. (citing Staff of House and Senate Conference on H.R. 2, 93d Cong., 2d Sess., Suinmary of Differences Between the Senate Version and the House Version of H.R. 2 to Provide for Pension Reform, pt. 3, at 33 (Comm. Print 1974) [hereinafter Conference Report], reprinted in LEGISLATIVE HISTORY OF ERISA, supra note 156, at 5151, 5283).

158. The language in the House Conference Report, "for purposes of any State law that regulates insurance" and that of the pre-conference House version, "for purposes of any law of any State regulating insurance" is strikingly similar, and different from that of the final conference version that passed, "for purposes of any law of any State purporting to regulate insurance." Therefore, it appears that the Conference Report was referring to the earlier House version rather than to the section as finally adopted. 
subject to subsequent study. ${ }^{159}$ The conference version of the bill broadened the preemption clause and retained the deemer clause without any time limit. ${ }^{160}$ At some point after the House and Senate versions were sent to the conference committee, the term "purporting" was added. ${ }^{161}$ The term did not appear im the House version, and the Senate version had no deemer clause at all. The legislative history of ERISA "contains no explanation whatsoever of the reason for enacting the deemer clause." 162

In light of this background, there are several possible explanations of the conference report statement. First, it should be noted that the statement is explicitly a general explanation. ${ }^{163}$ Because only the House version had a deemer clause when sent to the conference committee and this first deemer clause did not contain the word "purporting," it is possible that this explanation referred to the version of the deemer clause in H.R. 2., not the version finally passed by Congress. ${ }^{164}$ Such an error could have easily occurred simply as a matter of oversight, particularly if the person who drafted this statement liad not worked on the earlier version of H.R. 2. ${ }^{165}$ Such speculations are not very helpful im any definitive way, but they do empliasize that the legislative history relied upon in FMC Corp. is merely one sentence of general explanation prepared by a congressional staffer that found its way into the final House Conference Report. Because it provides no explanation of the intended function of the term "purporting," and is more consistent with an earlier House version, it should not be considered dispositive.

3. Justice Stevens's View of the Deemer Clause. Justice Stevens presents a different view of the deemer clause. His view is that although

159. See Conference Report, supra note 157, at 33-34, reprinted in 3 LEGISLATIVE HISTORY OF ERISA, supra note 156, at 5151, 5283-84.

160. Northern Group, 833 F.2d at 92.

161. FMC Corp., 111 S. Ct. at 413 (Stevens, J., dissenting).

162. Id. There are no cases or documents in the legislative history that report which menber of Congress added the term "purporting" to the final version of the conference bill. Neither is there any indication of when the term was added, but it inust have been during the work of the conference committee because it appeared in neither the House nor Senate pre-conference versions. See Conference Report, supra note 157, at 33, reprinted in 3 LEGISLATIVE HISTORY OF ERISA, supra note 156, at 5151,5283 .

163. The statennent appears in the House Conference Report prepared to aceoinpany H.R. 2. The report thus contains section by section general explanations of the difference between the conference "substitute" and the House and Senate versions. H.R. CONF. REP. No. 1280, supra note 152, at 383,1974 U.S.C.C.A.N. at 5162.

164. See supra note 152. The FMC Corp. inajority even noted that the House Conference Report describing the deemer clause ounits any reference to "purporting." See FMC Corp., 111 S. Ct. at 410.

165. Such an error could also have been intentional, so as to gloss over the addition of the term "purporting." 
the savings clause saves all state laws that regulate insurance, the deemer clause brings back within the scope of the preemption clause those laws that " 'purport to' regulate insurance companies or contracts-laws such as those which set forth the licensing and capitalization requirements for insurance companies or the minimum required provisions in insurance contracts."166 Further, for an insurance law to be re-injected into the scope of the preemption clause, it inust (1) deem welfare benefit plans to be insurance companies or other insurers, (2) regulate insurance companies or insurance contracts, and (3) purport to do so. ${ }^{167}$

Justice Stevens interprets the scope of the deemer clause to be narrower than that of the savings clause. Under his approach, the deeiner clause simply allows preemption of those state laws that expressly regulate insurance companies or insurance contracts, ${ }^{168}$ and these laws would be applicable to health plans only if states were allowed to deem them to be insurance companies. ${ }^{169}$ Justice Stevens says that "deemed," "imsurance company," and "purporting" are the key words of the deemer clause, but he seems to focus primarily upon the terms "insurance company" and "insurance contract." 170

Justice Stevens's view results largely from two principle ideas. First, Congress intended to protect ERISA plans from certain regulatory requireınents aimed specifically at insurance coinpanies, such as prescribed capital and surplus standards, the need for obtaining certificates from the state insurance authorities, and reserve requirements. ${ }^{171}$ Second, the deemer clause should not be allowed to preempt laws such as Pennsylvania's Motor Vehicle Responsibility Act, which, although arguably

166. FMC Corp., 111 S. Ct. at 414 (Stevens, J., dissenting).

167. See id. at 413-14.

168. See id. at 414. These laws could be thought of as "traditional insurance regulations."

169. See id.

170. See id. at 413. His detailed explanation of the type of regulation that he believes the deemer clause was designed to protect welfare benefit plans from suggests that it is the substance of the law that makes it the victim of the deemer clause. He lists laws setting hicensing and capitalization requirements for insurance companies as examples of such laws. He argues that Congress intended to protect welfare benefit plans from "the detailed regulatory provisions that typically apply to all state-regulated insurance companies." Id. Hence, his view of the decming and purporting requirements is that they are not the essence of what Congress was aiming at, but rather that they help identify the kind of insurance regulations sought to be preempted. Thus, his view would be that deeming is simply the necessary method that a state must use to bring welfare benefit plans within its insurance regulatory authority. This can be thought of as a relevance issue, because if the law to be preempted did not deem such plans to be insurance companies, a state's regulatory authority could not reach the plans; thus, Congress would have no interest in preempting them. His conceptualization suggests that he interprets the term "purporting" to inean simply that the law expressly states that it regulates or applies to insurance companies or insurance contracts. Hence, his view of "purporting" is essentially the same as that of the majority: they both assume that a law that purports to do soinething is a law that expressly says that it does such, and that such a law does what it says.

171. See id. 
purporting to regulate insurance, is actually far broader than the type of traditional insurance regulations described above because it addresses more than just insurance. Justice Stevens believes that both types of regulations are saved by the savings clause, but that regulations in the first category are brought back within the scope of preeinption by the deener clause because they "purport" to regulate insurance. ${ }^{172}$ According to his explanation, the deeiner clause "reinjects into the scope of ERISA preeinption only those state laws that 'purport to' regulate insurance coinpames or contracts."173

\section{Analysis and Critique of the Majority and Dissenting Opinions in FMC Corp.}

Botli the FMC Corp. majority and Justice Stevens misinterpreted the deeiner clause, largely because they have misread the qualifier "purporting to regulate." More specifically, because Justice Stevens thinks that "purporting to regulate" designates those laws that expressly regulate insurance, the vast majority of state laws regulating insurance would be preeinpted. ${ }^{174}$ This reading of the deemer clause tortures the plain langnage of the savings clause. ${ }^{175}$

The savings clause was intended to do precisely the opposite: to save insurance laws. The effect of Justice Stevens's view would be to leave to the savings clause inerely those laws that "aim to regulate another matter altogetlee, but also have the effect of regulating insurance." 176 Thus, the ouly insurance regulation that would be saved is that which is incidental to sone other kind of law. This is an unlikely interpretation of the plain language of the savings clause. Furthermore, it is inconsistent witl congressional intent to retain the states' traditional authority over insurance law.

172. See supra notes 123-26 and accompanying text. Recall that Stevens's view of the use of "purporting" is to refer to laws that are expressly aimed at insurance companies or insurance contracts. His dissent does not address the idea that "purporting" designates pretextual regulations. For the purpose of comparing his view to the majority's, the kind of insurance regulations that Justice Stevens believes are preempted will henceforth be referred to as "traditional insurance regulations."

173. FMC Corp., 111 S. Ct. at 414 (Stevens, J., dissenting).

174. Under his view, nearly all the regulations contained in state insurance codes would be preempted because they would purport to be aimed at insurance companies or insurance contracts.

175. For the language of the savings clause, see supra note 99.

176. FMC Corp., $111 \mathrm{~S}$. Ct. at 414. As an anti-subrogation statute, Pennsylvania's Motor Vehicle Financial Responsibility Act is an example of such a law. Justice Stevens's own words convey his idea best: "Such laws may regulate some aspects of the insurance business, but do not require one to be an insurance company in order to be subject to their terms." Id. 
The majority correctly recognized this feature of the congressional plan for saving most state imsurance laws from ERISA preemption. ${ }^{177}$ Moreover, the Metropolitan Life Court noted that "[t]he ERISA saving clause, with its similarly worded protection of 'any law of any State which regulates insurance,' appears to have been designed to preserve the McCarran-Ferguson Act's reservation of the busmess of imsurance to the States."178

The majority's interpretation of the deemer clause, however, misses the clarity and simplicity of ERISA's preemption scheme because the majority was distracted by the following apparent contradiction: The savings clause saves state laws that regulate imsurance; the deemer clause apparently prevents states from deeming ERISA plans to be insurance. Because many (if not all) ERISA welfare benefit plans provide health coverage, which is essentially health insurance, how can states be allowed to regulate insurance without regulating ERISA welfare benefit plans? This is the conceptual problem (the "inajority's paradox") upon which the majority's view founders.

Both the majority's and Justice Stevens's interpretations misread the final, qualifying phrase of the deemer clause-c"for purposes of any law of any State purporting to regulate insurance companies [or] insurance contracts."179 The majority mistakes the deemer clause for an absolute ban on direct regulation of ERISA health plans. Justice Stevens sees it as an absolute ban on "traditional insurance regulations" affecting all ERISA health plans. This simiply is not what the deeiner clause says. ${ }^{180}$

177. Even the FMC Corp. majority recognized that ERISA was intended to recognize the states' traditional role in regulating insurance. See FMC Corp., $111 \mathrm{~S}$. Ct. at 410 (citing Jones v. Rath Packing Co., 430 U.S. 519, 525 (1977) and the McCarran-Ferguson Act, 15 U.S.C. $§ 1012$ (a) (1988) ("The business of insurance, and every person engaged therein, shall be subject to the laws of the several States which relate to the regulation or taxation of such business.")).

178. Metropolitan Life Ins. Co. v. Massachusetts, 471 U.S. 724, 744 n.21 (1985). The Court also stated that "Congress' 'primary concern' in enacting McCarran-Ferguson was to "ensure that the States would continue to have the ability to tax and regulate the business of insurance.' " Id. (citing Group Life \& Health Ins. Co. v. Royal Drug Co., 440 U.S. 205, 217-18 (1979)). Other courts have similarly argued that Congress's intent in ERISA to "protect the participants and beneficiaries of group benefit and pension plans" is best served by respecting the "traditional deference given to state insurance regulations as inandated by the McCarran-Ferguson Act." Cathey v. Metropohtan Life Ins. Co., 805 S.W.2d 387, 393 (Tex. 1991) (Dogget, J., concurring) (citation omitted).

179. ERISA $\S 514(\mathrm{~b})(2)(B), 29$ U.S.C. $\$ 1144(\mathrm{~b})(2)(\mathrm{B})$.

180. The contrasting view developed in the next section is essentially that the deemer clause was intended to impose only a partial ban on the deeining of ERISA health plans to be insurance coinpanies or other insurers. Such deeming is prohibited only with respect to laws purporting to regulate insurance, meaning those laws that are actually aimed at regulatimg something else, but "purport" to be insurance laws becanse insurance laws are saved. See infra notes 193-95 and aecompanying text. 
Because the majority beheves the deemer clause to be an absolute ban on direct regulation of ERISA health plans, and because Justice Stevens beheves it to be an absolute ban on "traditional insurance regulations," they both agree that it somehow restricts the scope or the effect of the savings clause. ${ }^{181}$ In explaining its view of the relationship between the two clauses, the majority opinion states: "We view the language of the deemer clause, however, to be either coextensive with or broader, not narrower, than that of the saving clause."182 In the majority's view, although all insurance laws are saved, none may be apphed directly to health plans because such plans may not be deemed insurance companies or other insurers. Thus, the scope of the deemer clause is coextensive with the savings clause, and because no self-insured health plans may be deemed to be insurance coinpanies or other insurers, they cannot be regulated by state law for any purpose. ${ }^{183}$

Justice Stevens, on the one hand, writes: "[I]t is of critical importance to me that the category of state laws described im the saving clause is broader than the category described in the deemer clause."184 Because he believes that only "traditional insurance regulations" are preempted by the deenner clause, he thinks the savings clause is free to save all other imsurance laws, i.e., laws that do not purport to regulate insurance but have only an mcidental or tangential effect of regulating insurance. ${ }^{185}$ Thus, he views the deemer clause as "re-preempting" only a portion of what was saved by the savings clause. Accordingly, Justice Stevens has no need to create a distinction between self-insured and purchased plans. His distinction looks only to the character of the law in question, but leaves both the savings and deemer clauses to apply identically to both self-insured and purchased plans.

The majority, on the other hand, having stated that the deemer clause is coextensive with or broader than the savings clause, is faced with a paradox in that it must find meaning for the savings clause, i.e., something left for it to save. Having essentially ignored the term "purporting," the majority must find a different distinction between the two clauses than does Justice Stevens. Moreover, having read the deemer clause to mean that no ERISA health plans can be deemed to be insurers

181. See infra text accompanying note 186.

182. FMC Corp., $111 \mathrm{~S}$. Ct. at 411.

183. Under the same view, the scope of the deemer clause could be thought of as broader than that of the savings clause if the deemer clause restricted the application of such laws from more insurance than it allowed. For example, if self-insured plans were a larger source of health insurance than traditional, purchased indemnity plans, then the scope of the deemer clause could be thought of as broader because its impact in the marketplace of insurance would be greater than that of the savings clause. This has actually become the case. See supra notes 83-85 and accompanying text.

184. FMC Corp., 111 S. Ct. at 414 (Stevens, J., dissenting).

185. See supra notes $161-64$ and accompanying text. 
for any purpose (i.e., that they cannot be regulated directly), the Court must search for and find insurance that relates to ERISA welfare benefit plans ${ }^{186}$ but is not part of an ERISA welfare benefit plan so that states can regulate such insurance and the savings clause will have some insurance laws to save. At this unfortunate point in its reasoning, the Court is left with little clioice but to argue that "the saving clause retains the independent effect of protecting state insurance regulation of insurance contracts purchased by employee benefit plans," 187 hence the distinction between purcliased and self-insured plans.

Because the Court reads the deemer clause as an absolute ban on direct regulation of ERISA health plans, but finds that laws affecting insurance policies sold to such plans leaves soinething for the savings clause to save, this is a convenient resolution to the majority's paradox. Implicit in this conclusion, however, is the premise that regulating selfinsured plans would require deeming them to be insurance companies or other insurers. As a result of the Court's view that the deemer clause plainly prevents this, we are left by default with a distinction between self-insured and purchased plans that is nowliere to be found in the ERISA statute.

It is not apparent why the Court believes that a state would have to deem an ERISA plan to be an insurance company or other insurer in order to regulate the insurance activities of an employer who self-insures its ERISA plan. ${ }^{188}$ The same implicit reasoning by which the Court determines that states can regulate the policies that commercial carriers sell to employers for their ERISA plans-because the healtli plan and the insurance are separate ${ }^{189}$ - could apply just as readily to employers who self-insure their ERISA health plans. ${ }^{190}$ Although this argument may seein strained, it is conceptually valid. At the very least, it illustrates the

186. Recall that uuder the precmption clause, only those state laws that "relate to" pension or welfare benefit plans are preempted.

187. FMC Corp., 11 I S. Ct. at 411.

188. To say that such plans may not be "deemed" to be insurance companies or other insurers for purposes of pretextual state laws is not to say that they may not be so deemed for purposes of legitimate insurance laws. Neither is it to say that these health plans do not engage in activities that in fact are insurance, and are in all other circumstances regulated by the state.

189. Because the Court believes they are separate, it believes that the state can regulate the insurance without deeming the ERISA health plan to be an insurance company or other insurer.

190. If insurance regulation is saved, and if states can regulate the insurance policies sold to ERISA health plans, theu states should be allowed to regulate the insurance activities of companies who self-insure their ERISA plans. This Note rejects the Court's implicit argument that to regulate the insurance activity of ERISA health plans, states would have to "deem" such plans to be insurance companies or other insurers. In other words, if you can separate the plan and an insurance policy it buys, why can you not separate the plan from the insurance activities in which it engages? 
point that in order to solve one conceptual difficulty, the "majority's paradox," the Court created another. ${ }^{191}$

Criticizing the distinction that the majority creates between self-insured and purchased plans, Justice Stevens observed: "If Congress had intended such an irrational result, surely it would have expressed it in straightforward Englisli. At least one would expect that the reasons for drawing sucli an apparently irrational distinction would be discernible in the legislative history, or in the literature discussing the legislation."192 This distmction is purely the product of judicial, rather than legislative, creativity.

\section{E. An Alternative Interpretation of the Deemer Clause}

An examination of the phrase "purporting to regulate," in addition to a few observations about congressional intent and policy concerns, will suggest an obvious alternative interpretation of the deener clause.

1. "Purporting to Regulate" Is the Critical Phrase. As a inatter of statutory interpretation, the coinpeting interpretations of the deemer clause pivot dramatically depending on the reading given to the phrase "for purposes of any law of any State purporting to regulate imsurance." Purport is defined as "[t]hat whicli appears on the face of an instruinent ... [t]he apparent, but not necessarily the legal, import of the instrument." 193 In FMC Corp., the Court cites Black's Law Dictionary as defining "purporting" to inean "having the 'appearance of' or 'intending' to regulate insurance companies or contracts."194 Although all the courts and Justices agree that a law that purports to do something expressly gives the appearance of intending to do so, the FMC Corp. majority chose to ignore the remainder of the definition-that the appearance is not necessarily the legal import of the instrument. The majority's interpretation ignored the term "purporting" altogether, and thus by default appears to have adopted the view that all laws that "purport" to do something are laws that simply do what they appear to do.

As a matter of seniantics, Congress's use of the language "laws purporting to regulate" seems most likely to refer to pretextual laws. Were this not the case, the phrase could liave been left out of the deemer clause entirely without detraction. If the phrase is read in context, the $F M C$ Corp. Court's interpretation that laws "purporting to regulate insurance

191. But even this approach is unnecessary because, as will be explained more fully in the next section, the deemer's clause ban on deeming ERISA plans to be insurers is only a partial ban. See infra notes 193-95 and accompanying text.

192. FMC Corp., 111 S. Ct. at 412 (Stevens, J., dissenting).

193. Ballantine's Law Dictionary 1028 (3d ed. 1969) (citations omitted).

194. FMC Corp., $111 \mathrm{~S}$. Ct. at 410. 
companies" are laws that simply do what they appear to do, makes the phrase meaningless. ${ }^{195}$ If the Court's interpretation were correct, Congress could have more plainly and directly conveyed that idea by simply leaving off the last qualifying clause. ${ }^{196} \mathrm{~A}$ fundamental rule of statutory construction, however, requires courts to give effect to all terms employed and avoid rendering any terms superfluous. ${ }^{197}$

Statements in the legislative history demonstrate that at least some senators intended the deemer clause to prevent pretextual state laws or regulations. ${ }^{198}$ The Third Circuit noted that "[r]emarks froin two of the sponsorimg senators support the view that the use of 'purporting' betokens a congressional concern only for regulation that was merely a pretext for impinging upon ERISA plans." 199 Senator Javits stated that broad federal preemption was intended to bar " "[s]tate laws hastily contrived to deal with soine particular aspect of private welfare or pension benefit plans not clearly connected to the Federal regulatory scheme." 200 Senator Williams also displayed concern for pretextual state infringements, albeit in the context of professional regulation having the force of state law rather than state insurance laws themselves:

195. See id. (citing ERISA § 514(b)(2)(B), 29 U.S.C. § 1144(b)(2)(B)). Pretextual laws are not uncommon. Laws imposing literacy as a requirement for voting are an obvious example. See, eg., Louisiana v. Urited States, 380 U.S. 145 (1965); Davis v. Sclınell, 336 U.S. 933 (1949). Although such laws "purported" to be aimed at improving government by assuring that elections expressed the clioices of an "educated" electorate, the goal was simply to impede the right of many African-Americans to vote. In this hight, the majority's summary rejection of the idca that Congress simply intended to forestall state efforts to expand their insurance, banking, and securities regulatory authority seens curious.

196. Before the final qualifier (the "purporting" phrase), the deemer clause already provides that states may not deein welfare benefit plans to be "insurance companies" or "other imsurers." Because this inuch of the clause contains no restriction by purpose, it applies to all laws, including those "purporting to regulate insurance," which under the majority's view are laws that do whiat they say they do. The final qualifier is a restriction by purpose-" "for purposes of any law ... purporting to regulate insurance." Under the majority's view of "purporting to regulate," only those laws that do what they say they do would be brought back within the scope of the general preenption clause. Laws that did not, i.e., pretextual laws, wonld not. Hence, the ouly purpose for whicli states could deen welfare benefit plans to be insurance coinpanies or other insurers would be for purposes of pretextual laws. Such an absurd construction strongly suggests that Congress intended the distinction to be construed in the opposite manner, i.e., to prevent rather than to allow deeming for purposes of pretextual laws. The majority apparently would argue that deeming is not allowed for laws of either purpose, but that argument renders the final clause a nullity.

197. United States v. Handy, 761 F.2d 1279, 1280 (9th Cir. 1985).

198. See 120 CONG. ReC. 29,942 (1974) (statement of Sen. Javits) reprinted in 3 LEgisLative HisTORY OF ERISA, supra note 156, at 4771.

199. FMC Corp. v. Holliday, 885 F.2d 79, 86-87 (3d Cir. 1989).

200. Id. at 87 (quoting 120 CONG. REC. 29,942 (1974) (statement of Sen. Javits), reprinted in 3 LEGISLATIVE HISTORY OF ERISA, supra note 156, at 4771) (alteration and einphasis added by court). Although this quote supports the view that the deemer clause was ained at pretextual state laws, it also supports drawing a distinction based on the objective of such laws. It is used liere specifically for the first proposition. 
"State professional [associations] acting under the guise of State-enforced professional regulation, should not be able to prevent unions and einployers from maintaining the types of employee benefit programs which Congress has authorized ...."201

The Third Circuit adopted respondent Holliday's argument that the deenner clause excepts from the savings clause only those state insurance laws that are pretexts for "impinging upon core ERISA concerns."202 The FMC Corp. majority rejected the "core concerns" aspect of this view by accurately noting that there is nothing in ERISA's language to support the distinction. ${ }^{203}$ Accordingly, the Third Circuit's focus on the likely target ${ }^{204}$ of pretextual laws is unpersuasive. ${ }^{205}$ Whether the objective of a pretextual state regulation is core or tangential to the concerns of ERISA, the law would be equally assailable on grounds that it was a deceptive atteinpt to expand the scope of the state's insurance regulatory authority. Such a law would not fall within the pohicies behind the savings clause.

Justice Stevens recognized, as did the Third and Sixth Circuits, that "purporting" is one of the key terms of the deemer clause. However, he thought it simply denominated a particular subgroup of insurance regulations so that health plans may be deeined insurance conipanies for purposes of some insurance laws, but not others. ${ }^{206}$ Because his view would have the deemer clause brimg most insurance laws back within the effect of the preeniption clause, it is at odds with the plain language of the savings clause. ${ }^{207}$

201. Id. (quoting 120 CoNG. Rec. 29,933 (1974) (statement of Sen. Williams), reprinted in 3 LEGISLATIVE HISTORY OF ERISA, supra note 156, at 4746)) (emphasis added by court).

202. FMC Corp., 885 F.2d at 88. See supra notes 128-29 for an explanation of "core ERISA concerns."

203. See FMC Corp. v. Holliday, 111 S. Ct. 403, 410 (1990). As described above, the "core ERISA concerns" view injects a substantive criteria into the decmer clause. See supra notes 128-29 and accompanying text. Under this view, Congress's primary concern was with the attempt by states to expand the scope of their insurance regulatory authority by pretextual state laws aimed at core ERISA concerns. Hence, the creation of a distinction from expansions of regulatory authority by pretextual laws aimed at other things. This is the precise distinction that the majority says is not in the clause. Although the distinction is not in the clause, it would have been a reasonable option if Congress had only been worried about state forays into core ERISA concerns. Because the clause does not distinguish among the objectives of the prcempted state laws, it follows that Congress's goal was to prevent all attempts by states to expand their regulatory authority.

204. See FMC Corp., 885 F.2d at 88.

205. Although drawing a distinction based on the objective of pretextual laws would have been consistent with the general policy objectives behind ERISA, there is scant evidence of such intent and none in the final language adopted. See supra notes 128-29. Drawing a distinction between pretextual state laws aimed at core ERISA concerns and those aimed at other issues commits the error of "reading into the statute other distinctions that are not there," FMC Corp., 885 F.2d at 88, that the court later warns against. See supra note 128 and accompanying text.

206. See FMC Corp., 111 S. Ct. at 414 (Stevens, J., dissenting).

207. See supra note 99 and accompanying text. 
2. Congressional Intent. It is doubtful that Congress intended the disparate treatment of self-insured and purchased plans created by the inajority's interpretation. Had this been Congress's intent, it would have been simpler for Congress to have saved only those laws regulating cominercial insurance companies or the insurance contracts they sell. All other insurance laws would have been preempted without any need for a third clause, the deemer clause. Alternatively, as Justice Stevens noted:

Had Congress intended this result, it could have stated simply that "all

State laws are pre-einpted insofar as they relate to any self-insured employee plan." There would then have been no need for the "saving clause" to exempt state insurance laws from the preemption clause, or the "deemer clause," which the Court today reads as merely re-injecting into the scope of ERISA's preemption clause those same exempted state laws insofar as they related to self-insured plans. ${ }^{208}$

The majority's overly broad view of the preemptive effect of the deemer clause conflicts with Congress's express intent not to interfere with the states' traditional role in insurance. In addition to the clear language of the savings clause itself, Section 1144(d) provides that "[n]othing in this [subchapter] shall be construed to alter, aniend, modify, invalidate, impair, or supersede any law of the Umited States."209 When read together with the McCarran-Ferguson Act, ${ }^{210}$ these sections evince congressional intent not to disturb the traditional role of the states in regulating insurance. The Sixth Circuit described the effect of ERISA $\S 1144$ (d) and the McCarran-Ferguson Act, stating: "In the face of this redoubled statutory preservation of the principle favoring state regulation of insurance, it appears contrary to the overall legislative purpose to read the deemer clause broadly to bar all state regulation of self-insured plans."211 Even the Supreme Court observed that in this area of traditional state regulation there is a presumption "against preemption."212

The FMC Corp. majority asserts that its opinion is respectful of "the presumption that Congress does not intend to pre-einpt areas of traditional state regulation." 213 After citing the McCarran-Ferguson Act language, the majority noted that in Metropolitan Life they held that regulation of the "business of insurance" includes not just the regulation

208. FMC Corp., $111 \mathrm{~S}$. Ct. at 411 (Stevens, J., dissenting).

209. ERISA § 514(d), 29 U.S.C. § 1144(d). "Law of the United States" refers to federal law.

210. 15 U.S.C. $\S \S 1011-1015$ (1988); see supra note 108 and accoinpanying text.

211. Northern Group Servs., Inc. v. Auto Owners Ins. Co., 833 F.2d 85, 92 (6th Cir 1987); see also Metropolitan Life Ins. Co. v. Massachusetts, 471 U.S. 724, 744 n.21 (1985) (discussing the concern of Congress in enacting McCarran-Ferguson as being that of ensuring continuing state regulation of insurance).

212. Metropolitan Life, 471 U.S. at 741; see also Wadsworth v. Whaland, 562 F.2d 70, 75-76 (1st Cir. 1977), cert. denied, 435 U.S. 980 (1978).

213. FMC Corp., 111 S. Ct. at 410 (citing Jones v. Rath Packing Co., 430 U.S. 519, 525 (1977)). 
of insurance companies, but also the regulation of the "substantive terms of insurance contracts." 214 The Court's assertion that its holding respects "Congress' presumed desire to reserve to the States the regulation of the 'business of insurance" "215 assumes without analysis that self-insured plans are not imsurance. ${ }^{216}$

Because the health plans administered by self-msured welfare benefit plans are conceptually the same as insurance contracts purchased by other employers, it is unclear why the Court beheves that self-insured plans are not included within the term "business of insurance" but that imsurance contracts are. ${ }^{217}$ I beheve that the Court excludes self-insured health plans from the term "business of insurance" not because they are not insurance, but rather, because in its view, the deemer clause prevents state regulation of the plans. Because state laws regulating the "business of insurance" are exphcitly saved, the Court felt obliged to distinguish self-insured health plans from the business of insuranee. Had the Court wanted to be truly faithful to the Metropolitan Life Court's approach ${ }^{218}$ and to congressional intent, the Court should have apphed the McCarran-Ferguson three-part test to determine "whether a particular practice falls within the Act's reference to the 'business of insurance.' "'219

3. Additional Policy Concerns. The most persuasive part of Justice Stevens's dissent is his objection to the majority's distinction between self-insured and purchased plans. He writes: "The Court's construction of the statute draws a broad and illogical distinction between benefit plans that are funded by the einployer (self-insured plans) and those that are insured by regulated insurance compames (insured plans)."220 $\mathrm{He}$ explams that "[f]rom the standpoint of the beneficiaries of ERISA

214. Id. (citing Metropolitan Life, 471 U.S. at 742-44).

215. Id.

216. The full sentence reads:

By recognizing a distinction between insurers of plans and the contracts of those insurers, which are subjeet to direct state regulation, and self-insured employee benefit plans governed by ERISA, which are not, we observe Congress' presumed desire to reserve to the States the regulation of the "business of insurance."

Id. (emphasis added). Note here that the Court's deelaration that self-insured employee benefit plans are not included within the term "business of insurance" contains neither analysis nor authority beyond the authority of the Court.

217. Although the precise terms of each self-insured health plan are set by the employer and the plan's administrator (as are the precise terms of a group health policy purchased by an employer for its employees), the essential features of each are the collection of preiniuns (paid by either the eunployer, employee, or both) into a fund from which benefits are paid. For each type of plan, the practice has become to set the premium level annually based on the claims experience of the group during the preceding year. See supra notes 28-29 and accompanying text.

218. See supra note 108 and accompanying text.

219. Metropolitan Life, 471 U.S. at 743. For the three-part test, see supra note 110.

220. FMC Corp., 111 S. Ct. at 411 (Stevens, J., dissenting). 
plans-who after all are the primary beneficiaries of the entire statutory program-there is no apparent reason for treating self-insured plans differently from insured plans."221

Bearing in mind the similarity between self-insured and purchased plans, ${ }^{222}$ I would extend Justice Stevens's point about dissimilar treatment of similarly situated beneficiaries one step further: There is no reason at all for disparate treatment. Beneficiaries of plans that purchase insurance should not have all the protection afforded by state insurance law while beneficiaries of self-insured plans are demied all such protection. Justice Stevens argues that "[t]he notion that this disparate treatinent of similarly situated beneficiaries is somehow supported by an interest in uniformity is singularly unpersuasive."223 It is a fundamental principle of equity that the law treat similarly situated claimants similarly. ${ }^{224}$ Thus, it is hard to see why two beneficiaries with the same injury or illness resulting in the same state law claim agamst a plan administrator should be treated differently depending solely upon who holds the corpus of the insurance fund, the employer or a commercial insurance coinpany.

In hight of the foregoing discussion, a more plausible interpretation of the deemer clause is that it prohibits states from regulating ERISA plans through any pretextual laws. Rather than preempting those laws ained at core ERISA concerns, or those laws that expressly regulate insurance, the deeiner clause should be interpreted to preempt all laws that merely purport to regulate insurance compamies or insurance contracts, but are, in fact, aimed at something else. Examples could include state laws aimed at labor issues, or employee benefits absent an insurance mechamism (such as sick leave), or agency law affecting the relationship

221. Id. Other courts have also noted the irony in turning a law that was supposed to protect pension and benefit plan beneficiaries into a law that, in effect, eliminates protection. Justice Doggett of the Texas Supreme Court, commenting on the expansion of ERISA precmption announced in Pilot Life, observed:

[T]he United States Supreme Court has restricted the very rights of employees-to avoid the delay or denial of benefits--that Congress sought to protect. Through peculiar federal judicial interpretation, a statutory addition to workers' rights has been converted into $a$ statutory removal of those rights. The law has been reshaped into a form that achieves the converse of its original purpose. ... I jom with the growing number of courts and cominentators who express the concern that through continued misconstruction, ERISA has beconve "quicksand" that "will continue to expand and to preempt everything in its ineandering path."

Cathey v. Metropolitan Life Ins. Co., 805 S.W.2d 387, 392 (Tex.) (Doggett, J., concurring) (emphasis added), cert. denied, 111 S. Ct. 2855 (1991).

222. The primary conceptual difference between self-insured and commercial plans is whether the employer or the insurance company will hold and control the fund generated from the premiums or contributions.

223. FMC Corp., $111 \mathrm{~S}$. Ct. at 411-12 (Stevens, J., dissenting).

224. See generally John E. MURRAY, JR., Murray ON Contracts (3d ed. 1990). 
between a plan administrator and plan beneficiaries. If a state attempted to characterize such regulations as having some relation to a benefit plan with an insurance mechamism, they would thereby "purport" to be insurance regulations, but in fact be benefit plan regulations.

The purpose of the deemer clause (in relation to the savimgs and preemption clauses) was to make clear that states would not be allowed deceptively to deem ERISA health plans to be imsurance. Similarly, it was imtended to prevent state attempts to regulate non-insurance-related aspects of ERISA health plans through lavis deceptively characterized as regulating insurance or through incorporating such provisions into bona fide imsurance laws. In other words, Congress intended to emphasize that, although states would retain all their authority (recoguized in the savings clause) to regulate insurance, banking, and securities, this authority could not be increased through expansive or creative deelming or purportimg.225 Such activity would have undermined Congress's clearly stated policy choice to preempt all state laws that relate to ERISA plans.

The ouly exceptions to the preenption clause, and thus the only laws allowed to relate to ERISA plans, are laws in one of the three categories expressly saved: imsurance, banking, and securities. Therefore, although states retain all of their regulatory authority in these traditional areas with respect to all ERISA plans, the deemer clause was intended to prevent the expansion of their regulatory authority. The deemer clause was meant simply to strengthen and clarify this demarcation between federal and state regulatory authority. It was also intended to forestall any attempt by states to expand the scope of their saved regulatory authority through deceptive characterizations.

This interpretation is reinforced by the approach adopted in Metropolitan Life with respect to determining what activities qualify as the business of insurance. 226 The Court noted Congress's apparent intent to maintain the McCarran-Ferguson Act's allocation of insurance regulation to the states. ${ }^{227}$ The Court then employed the McCarran-Ferguson three-part test for the "business of insurance."228 The significance of the Court's employment of the McCarran-Ferguson standard to define the scope of the savings clause is that it reflects Congress's intent to insure that the parameters of the savings clause were established by federal law, not left to the discretion of state legislators or insurance commissioners.

225. Intentional expansions by states under the guise of their insurance regulatory authority would be pretextual. Unintentional expansions may be made in good faith and thus not pretextual, but would still be proscribed by the deemer clause if determined by a federal court to be beyond the scope of the states' insurance regulatory authority as preserved under the savings clause.

226. See Metropolitan Life Ins. Co. v. Massachusetts, 471 U.S. 724, 743-44 (1985).

227. See id. at 742-43, 745-46.

228. See id. at 743-44. 
Thus, the deemer clause serves to make clear that the scope of the savings clause cannot be broadened by the states. Were this not the case, ERISA's preemption scheme would have contained a gap that would have allowed states to quibble over the definition of msurance or banking. Had this been allowed, the states would have had a powerful weapon for undermining the effect of congressional preemption. ${ }^{229}$

This alternative interpretation offers one substantial advantage over Justice Stevens's view: It is consistent with Congress' basic policy choice to save state insurance law. Because Justice Stevens's interpretation would have the effect of preempting all "traditional" insurance law, it creates tremendous tension with the savings clause. This interpretation also avoids the unnecessary complexities, conceptual difficulties, and anomalous results of the majority's view in FMC Corp.

By allowing state msurance law to apply to self-msured and purchased health plans alike, this alternative interpretation would eliminate employers' efforts to circumvent state law by switching to self-insured plans to avoid the requirements of state law. Of course, this interpretation only restores the effect of state insurance law to all health plans. Thus, it is useful to curb the abuses described in Part I only to the extent that states have adopted or will adopt insurance laws that prevent singling out PWAs or gay men for disparate treatment under einployerprovided health plans.

\section{CONCLUSION}

The language and legislative history of the deemer clause provide such a mixed and ambiguous record that reasonable arguments can be made to support all of the interpretations discussed above. At this poimt, it is highly unlikely that anyone could demonstrate persuasively that Congress intended any one of these interpretations to the exclusion of all others. Based on the available record, the best that can be hoped for is an interpretation that is supportable by both the plam language and legislative history of the preemption, savings, and deemer clauses. The optimal interpretation would also strike a reasonable balance between the competimg policy goals of the three preemption sections without creating grossly anomalous resnlts.

The FMC Corp. majority's interpretation disregards a portion of both the deemer clause and its legislative history. More importantly, it creates an inequitable disparity between beneficiaries of self-insured and

229. It would have allowed, in effect, the federal government to preempt all laws that relate to ERISA plans except insurance, banking, and securities, while also allowing the states to define what insurance, banking, and securities are. Federal precmption would thus have been substantially vitiated. 
purchased plans. To the extent that PWAs have been and will likely continue to be among the most severely injured through employers' exploitation of the Supreme Court's holding, the consequences are lifethreatening and deserve immediate attention.

The alternative interpretation offered by this Note-that the deemer clause inerely prevents states froin expanding their regulatory authority retained under the savings clause by assuring that federal rather than state law will control the definition of insurance-avoids the disadvantages of the others. This is the only interpretation suggested so far that is consistent with both of Congress's broad policy goals in Section 1144: (1) preeinption of the field of einployee pension and welfare benefit plans except for (2) the expressly saved state laws that actually regulate insurance, banking, or securities. This interpretation would return the protection of state insurance law to the beneficiaries of all ERISA welfare benefit plans. Moreover, to the extent that states have inandatory ininimum benefit laws or laws that prohibit discrimination against PWAs, this interpretation wonld prevent employers' benefit discrimination against PWAs. It would, therefore, eliminate the double threat AIDS patients face under the current view of ERISA. Finally, this interpretation does not read into the statute any anoinalous or arbitrary distinctions.

Until the law is changed or the Supreme Court reexanmes its view, lawyers representing beneficiaries of self-insured plans can argue for an alternative application of the deener clause. Incorporating the Court's distinction betwecn direct and indirect regulation, there is no apparent reason why a state could not apply its law to the insurance aspect of a self-insured plan without necessarily deeming the plan to be an insurance company. This is consistent with the thrust of the Court's analysis that insurance can be regulated but ERISA plans cannot. If the insurance aspect of a plan can be conceptually separated from a plan that purchases insurance, there is nothing in the statute or the Court's interpretation that should prohibit the same conceptual separation when a plan selfinsures. 